\title{
45. SILICICLASTIC SEDIMENTS AT SITES 588, 590, AND 591: NEOGENE AND PALEOGENE EVOLUTION IN THE SOUTHWEST PACIFIC AND AUSTRALIAN CLIMATE ${ }^{1}$
}

\author{
R. Stein, Geologisch-Palaeontologisches Institut Kiel \\ and \\ C. Robert, Géologie Marine, Faculté des Sciences de Luminy, Marseille²
}

\begin{abstract}
Clay minerals, grain sizes, and flux rates of terrigenous sediments in the Lord Howe Rise area provide important information about the Neogene evolution of climate and physical processes in the southwest Pacific region. Temporal variations in these data suggest that the Neogene history of desertification in Australia was controlled by both the northward drift of the Indo-Australian Plate and the buildup of Antarctic ice sheets. Increased aridity, as defined by a distinct decrease in smectite/illite ratios and increased accumulation rates of terrigenous matter, occurred in northern Australia about 13 m.y. ago, expanding to the south during the late Miocene. Periods of maximum aridity coincided with major cooling events near $12,9,5$, and $3 \mathrm{~m} . \mathrm{y}$. ago. Increased eolian sediment supply and intensified atmospheric circulation are inferred from the grain size and flux rates of the terrigenous sediments at Site 591 during the last $4 \mathrm{~m} . y$., that is, about $0.8 \mathrm{~m} . \mathrm{y}$. earlier than similar observations recorded in the Northern Hemisphere. An enhanced oceanic intermediate-water circulation is inferred from decreased accumulation rates and a coarsening of both the bulk-sediment and the terrigenous-sediment fraction at Sites 588 and 590 during the last $3 \mathrm{~m} . \mathrm{y}$.

Volcanic activity increased in the southwest Pacific region during the Miocene ( 21 to 9 m.y. ago) and in the Quaternary $(0.4 \mathrm{~m} . \mathrm{y}$. ago).
\end{abstract}

\section{INTRODUCTION}

During Leg 90 of the Deep Sea Drilling Project, Sites $588,590,591$, and 592 were drilled along a latitudinal transect on the Lord Howe Rise between 26 and $36^{\circ} \mathrm{S}$ at water depths between about 1000 and $2100 \mathrm{~m}$ (Fig. 1, Table 1). The sediments range in age from the middle Eocene (Site 588) or early Miocene (Sites 590, 591) to the Pleistocene and consist of foraminifer-bearing nannofossil oozes and chalks to nannofossil oozes and chalks (site chapters, this vol.). The use of the hydraulic piston corer (HPC) and-in greater sub-bottom depths-the extended core barrel (XCB) facilitated a very good recovery and high quality for all sediment sections and provided excellent material for studying the paleoclimatology and paleoceanography of the southwest Pacific region.

The purpose of this study is to reconstruct paleoenvironments from the investigation of the mineralogy, grain size, and flux rate of the terrigenous (i.e., carbonatefree, nonauthigenic, inorganic) sediment fraction (Fig. 2). The main objectives were to understand (1) the evolution of the Australian climate, (2) changes in atmospheric and oceanic circulation in the southwest Pacific region, (3) phases of volcanic activities, and (4) the northward drift of the Indo-Australian Plate as reflected in the marine terrigenous sediments at the Lord Howe Rise.

As shown by previous studies from other ocean regions, investigations of the terrigenous sediment frac-

\footnotetext{
${ }^{1}$ Kennett, J. P., von der Borch, C. C., et al., Init. Repts. DSDP, 90: Washington (U.S. Govt, Printing Office).

2 Addresses: (Stein, present address) Institute for Petroleum and Organic Geochemistry (ICH 5), Kernforschungsanlage Jülich GmbH, P.O. Box 1913, 5170 Jülich, Federal Republic of Germany; (Robert) Géologie Marine, URA CNRS 41, Faculté des Sciences de Luminy, Case 901, 13288 Marseille Cedex 9, France.
}

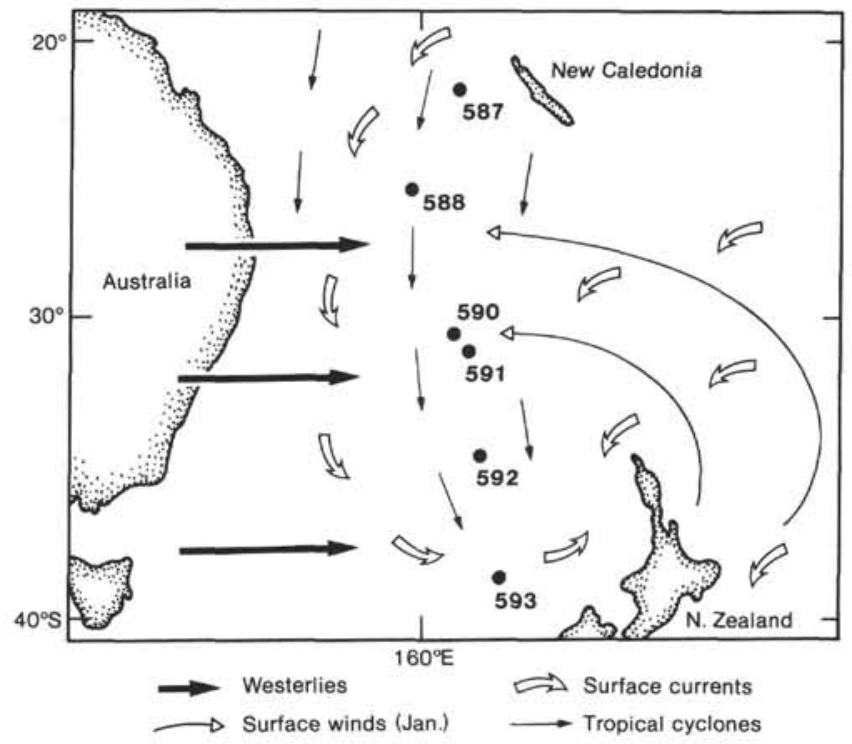

Figure 1. Positions of the Leg 90 sites drilled on the Lord Howe Rise, and the dominant atmospheric and oceanic surface circulation patterns in the southwest Pacific (according to Knox, 1970; Ramage, 1970).

tion can provide a useful record of paleoclimate and paleoceanography. Clay mineral analyses can provide information about the origin of detrital minerals and the climate of the source area as well as volcanic and tectonic activity (Biscaye, 1965; Griffin et al., 1968; Chamley, 1979; Chamley and Robert, 1979; Leinen and Heath, 1981; Lange, 1982; Robert, 1982; Sarnthein et al., 1982; Maillot and Robert, 1984; Stein, 1984; Stein and Sarnthein, 1984a). If the terrigenous sediment supply is mainly eolian in origin, wind intensity of past times can be 
Table 1. Site locations and water depths.

\begin{tabular}{|c|c|c|c|}
\hline Site & Latitude (S) & Longitude (E) & $\begin{array}{c}\text { Water } \\
\text { depth } \\
\text { (m) }\end{array}$ \\
\hline 588 & $26^{\circ} 06.70^{\prime}$ & $161^{\circ} 13.60^{\prime}$ & 1533 \\
\hline 590 & $31^{\circ} 10.02^{\prime}$ & $163^{\circ} 21.51^{\prime}$ & 1299 \\
\hline 591 & $31^{\circ} 35.06^{\prime}$ & $164^{\circ} 26.92^{\prime}$ & 2131 \\
\hline 592 & $36^{\prime} 28.40^{\prime}$ & $165^{\circ} 26.53^{\prime}$ & 1098 \\
\hline
\end{tabular}

deduced from the grain-size distribution of the terrigenous matter (Parkin, 1974; Leinen and Heath, 1981; Sarnthein et al., 1981; Rea and Janecek, 1982; Janecek and Rea, 1983; Lever and McCave, 1983; Stein 1984, 1985a). The flux rates of dust may yield additional information on the aridity of the source area because erosion initially increases as vegetation cover decreases (Parkin and Padgham, 1975; Leinen and Heath, 1981; Rea and Janecek, 1982; Stein and Sarnthein, 1984a). In contrast, the dust flux from a mature sand and stone desert is minor, although still significantly more than from a humid vegetation area. Therefore, maximum dust-flux rates are recorded in areas of semiarid climate such as in the southern Sahara and the Sahelian zone (Carlson and Prospero, 1977; Sarnthein et al., 1982).

\section{THE MODERN REGIME OF SEDIMENT DISTRIBUTION PATTERNS IN THE SOUTHWEST PACIFIC}

\section{Origin and Significance of Clay Minerals}

Smectite can be formed by the weathering of volcanic products and by pedogenic processes in a humid to semi- arid climatic regime characterized by areas with low relief and poorly drained environments (Millot, 1964; Chamley et al., 1984). Climatic conditions favorable for the formation of smectite are found in the north and northeast regions of Australia and in the semiarid belts enclosing the central Australian deserts (Pedro, 1968) as well as in southern Australia (Moriarty, 1977).

Regions with high relief and active tectonism as well as areas with temperate to cold or hot, dry climatic conditions, that is, areas with dominant physical weathering, favor the formation of illite, chlorite, and irregular mixed-layer clays (Chamley, 1979; Robert, 1982).

Kaolinite is preferentially formed under tropical conditions where chemical weathering dominates, such as in the lateritic zones in equatorial Africa (Millot, 1964; Biscaye, 1965; Chester et al., 1971). Thus, kaolinite-rich soils found today in arid to semiarid areas of central Australia (Griffin et al., 1968; Moriarty, 1977) may have been formed during earlier, more humid climatic periods.

\section{Sources of Detrital Materials at the Lord Howe Rise}

Several source areas of terrigenous matter and different transport systems must be distinguished if the variations in the terrigenous sediments at the Lord Howe Rise are to be used as a record of paleoclimate and paleoceanography (Fig. 1).

\section{Eolian Sediment Supply}

The importance of wind-borne material for the sediment budget of siliciclastic matter in the southwest Pacific region has been recorded in several previous studies (Marshall and Kidson, 1929; Kidson, 1930; Loewe, 1943;

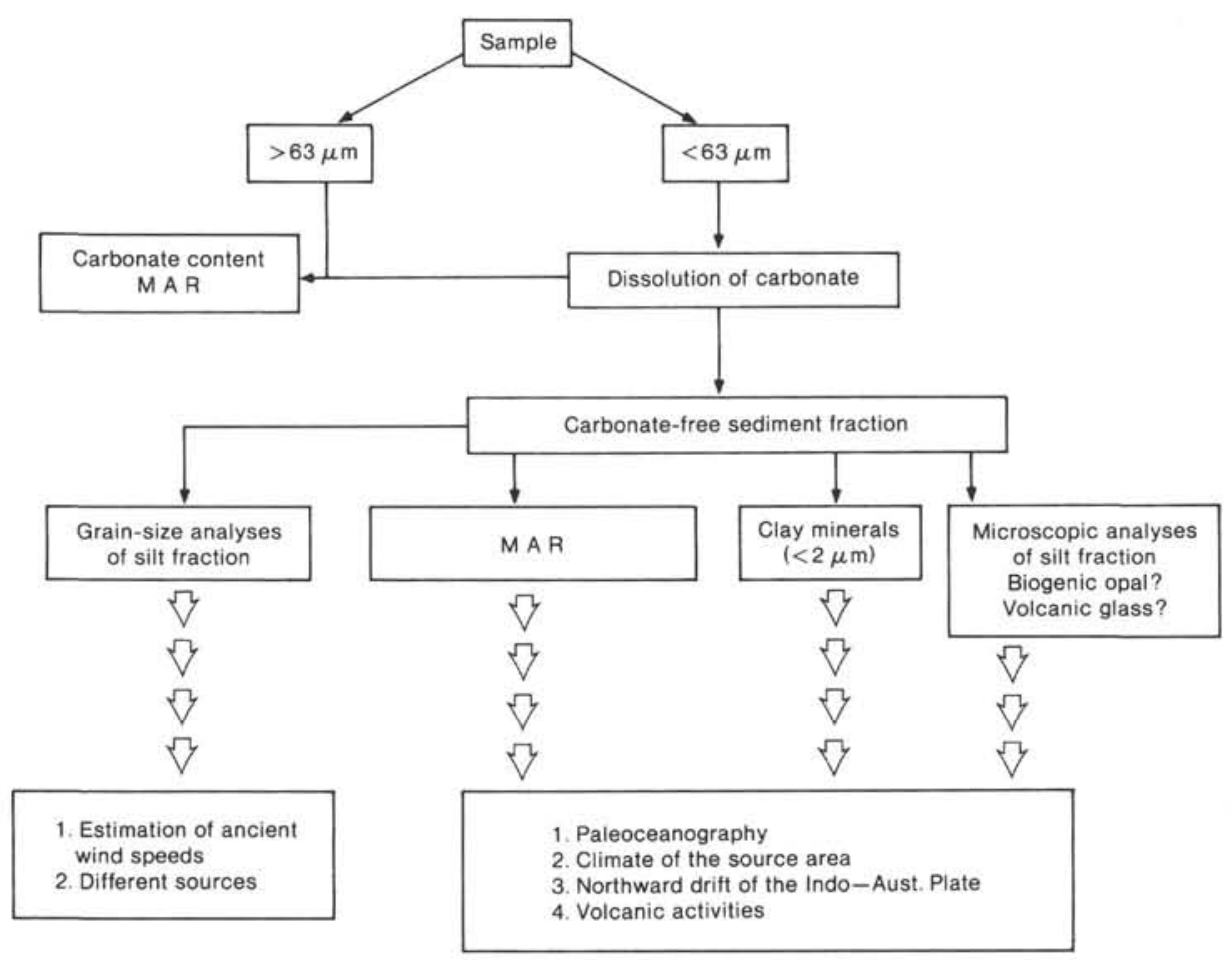

Figure 2. Flow chart of the methods used to determine grain size and composition of the carbonatefree silt fraction, mass accumulation rates (MAR), and clay mineralogy. 
Healy, 1970; Glasby, 1971; Walker and Costin, 1971; Thiede, 1979).

The terrigenous sediment supply in the area investigated is restricted mainly to eolian dust, because the Lord Howe Rise lies more than $1000 \mathrm{~km}$ offshore and is separated from the Australian continental margin by the Tasman Abyssal Plain. This prevents a supply of fluvial terrigenous matter by turbidity currents. At present, the eolian sediment flux is dominated by westerly winds bringing dust from the Australian deserts and semideserts (Fig. 1; Healy, 1970; Glasby, 1971; Sprigg, 1982). The eolian origin of the sediments is also indicated by the (eolian) quartz content in recent deep-sea sediments from the Tasman Sea, which show a distinct decrease from the Australian continent toward the east (Thiede, 1979). Kaolinite and illite in the dust are probably derived from the western and central deserts and semidesert regions and the eastern highlands of Australia, where they are dominant components of the fine-sediment fraction (Griffin et al., 1968; Moriarty, 1977; Mienert, 1981). The clay mineralogy of dust samples collected from snowfields in southeastern Australia is also dominated by illite and kaolinite (Walker and Costin, 1971).

In addition to the eolian sediment supplied by the westerlies, dust may be supplied by two other wind systems. Surface winds may carry dust from New Zealand during the southern summer, and tropical cyclones may supply dust from the northern tropical regions (e.g., the Melanesian islands) (Fig. 1; Ramage, 1970). Today, the eolian sediment flux of these two transport systems is negligible because the vegetation cover is thick in these areas and volcanicity is absent. However, during phases of volcanic activity in the tropical southwest Pacific regions and in New Zealand and during phases of both tectonic events and more arid climatic conditions in New Zealand, the two wind systems may have become important agents of eolian transport toward the Lord Howe Rise (see Nelson et al., this vol.).

\section{Advective Transport of Detritus by Currents}

In addition to the eolian sediment supply by winds, oceanic currents may also influence the terrigenous sediment balance at the Lord Howe Rise (Fig. 1). The East Australian Current flows southward off the eastern coast of Australia; it reaches maximum velocities of about $175 \mathrm{~cm} / \mathrm{s}$ in the upper $100 \mathrm{~m}$ and decreases to $10-20 \mathrm{~cm} / \mathrm{s}$ in 1200-m water depth (Fig. 1; Hamon, 1970). This current may supply clay-sized material from tropical regions north of the Lord Howe Rise and from Australia. Antarctic Intermediate Water enters the region from the east between 10 and $30^{\circ} \mathrm{S}$ (Wyrtki, 1962) and may also influence the flux of siliciclastic matter. Or if the currents reach a critical velocity, they may also winnow the fine fraction; this may be indicated by reduced bulk accumulation rates and a parallel coarsening of the grain sizes of both the bulk sediment and the terrigenous sediment fraction (Stein, 1984; Stein and Sarnthein, 1984b). At present, the advective transport of detritus toward the Lord Howe Rise seems to be of minor importance, as can be inferred from the similarity of dust-flux rates and terrigenous accumulation rates in the southwest Pacific region (Windom, 1969; Glasby, 1971). Thus, the carbonate- and biogenic-opal-free, nonauthigenic sediment fraction on the Lord Howe Rise is probably mainly eolian in origin.

\section{METHODS}

The methodology used for this study is outlined in Figure 2. Because the carbonate-free sediment fraction was very small, it was not possible to determine all sediment parameters from the same sample. Thus, one set of samples was used for carbonate measurements, grainsize analyses, and component analyses of the carbonate-free silt fraction, and another set of samples was used for clay mineral analyses.

\section{Clay Mineral Analyses}

The fraction less than $63 \mu \mathrm{m}$ was decalcified in 0.2 hydrochloric acid and the excess acid removed by repeated washing and centrifugation followed by homogenization. The fraction less than $2 \mu \mathrm{m}$ was separated by decantation and was fixed as oriented aggregates on glass slides. Three X-ray diffractograms were made using (1) an untreated sample, (2) a glycolated sample, and (3) a sample heated for $2 \mathrm{hr}$. at $490^{\circ} \mathrm{C}$. A C.G.R. Theta 60 diffractometer (copper $\mathrm{K} \alpha$ radiation focused by a quartz curved monochromator) was used at scanning speeds of $1^{\circ} 2 \theta / \mathrm{min}$. A receiving slit of $1.25 \mathrm{~mm}$ allowed a more precise resolution of poorly crystallized minerals. Semiquantitative evaluations were based on the peak heights and areas. The data presented in Figures 4 through 6 are given in percentages, with the relative error being $\pm 5 \%$ per total clay. The relative abundances of smectite versus illite ( $\mathrm{S} / \mathrm{I}$ index) and of kaolinite versus illite (K/I index) were obtained from the ratios of the 001 smectite $(18 \AA)$, illite $(10 \AA)$, and kaolinite $(7 \AA)$ peaks on the glycolated sample.

The morphology of the smectites was studied by transmission electron microscope (Chamley, 1980; Chamley et al., 1984; Holtzapffel et al., 1984). The fraction less than $8 \mu \mathrm{m}$ was separated by decantation and the particles were scattered in a solution of tert-Butylamin. A drop of the suspension was then deposited on a copper grid which had been previously recovered by a membrane of Collodion. The analyses were performed using a Philips EM 300 electron microscope.

\section{Carbonate Conten}

Total carbonate- $\mathrm{CO}_{2}$ and carbonate- $\mathrm{CO}_{2}$ of the fraction less than $63 \mu \mathrm{m}$ were determined from a subsample by infrared absorption of $\mathrm{CO}_{2}$ after carbonates were dissolved in hot phosphoric acid. A factor of 2.274 was used to convert $\mathrm{CO}_{2}$ values into $\mathrm{CaCO}_{3}$ values, taking calcite as the predominant carbonate mineral. The analytical precision of this method is about $\pm 2 \%$ (Stein, 1984).

\section{Composition and Grain Size of the Carbonate-Free Sediment} Fraction

The samples were washed through a $63-\mu \mathrm{m}$ sieve. The fraction less than $63 \mu \mathrm{m}$ was treated successively with hydrogen peroxide and acetic acid to remove organic matter and calcium carbonate. The carbonatefree sediment fraction was separated into $>6 \mu \mathrm{m}$ and $<6 \mu \mathrm{m}$ subfractions by the Atterberg method (Mueller, 1967). The $>6 \mu \mathrm{m}$ fraction was analyzed for the percentage of biogenic opal and volcanic glass by smear-slide counts under a microscope. The terrigenous sediment fraction $>6 \mu \mathrm{m}$ presented in Figure 9 was calculated by subtracting biogenic opal $>6 \mu \mathrm{m}$ from the carbonate-free sediment fraction $>6 \mu \mathrm{m}$. The grain-size distribution of the 6 to $63 \mu \mathrm{m}$ size-fraction was determined using a Coulter Counter, Model T (McCave and Jarvis, 1973; Stein, 1985b).

\section{Mass Accumulation Rates}

Linear sedimentation rates (LSR) and mass accumulation rates (MAR) can be used to describe the rate of deposition of sediment in the ocean. The LSR, that is, the thickness of a sediment section per time interval, does not take into account the compaction of the accumulated sediment with increasing overburden and age. Thus, it is not meaningful to compare LSR from different sub-bottom depths (van 
Andel et al., 1975). Using MAR, the compaction problem can be eliminated, and a comparison of sediment accumulation on both a temporal and areal basis is possible.

The MAR were calculated according to van Andel et al. (1975) and Thiede et al. (1982) using mean porosity $(P o)$ and wet-bulk density $\left(\rho_{\text {wet }}\right)$ data of Morin (site chapters, this vol.) and the LSR (Fig. 3):

$$
\begin{aligned}
\operatorname{MAR}\left(\mathrm{g} \cdot \mathrm{cm}^{-2} 10^{-3} \mathrm{y}^{-1}\right) & =\operatorname{LSR} \cdot \rho_{\text {dry }} \\
& =\operatorname{LSR} \cdot\left(\rho_{\text {wet }}-1.026 \cdot \frac{P o}{100}\right),
\end{aligned}
$$

whereby LSR $=$ sedimentation rate $\left(\mathrm{cm} \cdot 10^{-3} \mathrm{y}^{-1}\right), \rho_{\text {dry }}=$ dry-bulk density $\left(\mathrm{g} \cdot \mathrm{cm}^{-3}\right)$, and $1.026=$ density of interstitial water $\left(\mathrm{g} \cdot \mathrm{cm}^{-3}\right)$. The LSR (Fig. 3) were based on the nannofossil biostratigraphy of Lohman (this vol.) and Martini (this vol.). The MAR of the carbonate-free sediment fraction can then be calculated by multiplying the MAR by the wt. \% total carbonate-free (i.e., mainly terrigenous) sediment fraction:

$$
\text { MART }=\text { MAR } \cdot \frac{\% \text { terrigenous sediment }}{100} .
$$

That is, we interpret the MAR of the carbonate-free sediment as the MAR of the terrigenous matter (MART), an assumption which seems to be permissible because (1) the carbonate-free sediment fraction contains almost no authigenic clay minerals (zeolites are absent or occur only in trace amounts; Figs. 4 to 6) and (2) biogenic opal is generally absent or occurs only in minor quantities (Figs. 4 to 6). An exception may be the late Miocene time interval at Site 591 (i.e., 350 to $200 \mathrm{~m}$ sub-bottom; Fig. 6) where higher abundances of biogenic opal were recorded. This would imply that the already low MART of this time interval (see Fig. 11, later) would become even lower.

\section{RESULTS $^{3}$}

\section{Coarse Fraction Abundance}

The contents of the fraction greater than $63 \mu \mathrm{m}$, mainly planktonic foraminifers, vary between 5 and $50 \%$ at all three sites (Figs. 4, 5, 6, and 7). Values of less than $10 \%$ are observed in the late Oligocene (Site 588) and in the late Miocene to Pliocene, between 8 and 3.5 m.y. ago (Sites 588, 590, and 591). Moderate percentages of coarse fraction (10 to $20 \%$ ) occur between 20 and 8 m.y. ago (Site 588). It was not meaningful to determine the $>63$ $\mu \mathrm{m}$ percentages by wet sieving for samples from Sites 590 and 591 from core depths greater than $280 \mathrm{~m}$ ( 8 m.y.) and $340 \mathrm{~m}(10 \mathrm{~m} . \mathrm{y}$.$) , respectively, because of diagenetic$ formation of aggregates (Fig. 7). These levels coincide with the transition from ooze to chalk (site chapters, this vol.). A more or less distinct increase in the coarse fraction has occurred in all Leg 90 sites at the Lord Howe Rise during the last 3 m.y. This increase is more distinct at the shallower Sites 588, 590, and 592 than at the deeper Site 591 (Fig. 7).

\footnotetext{
${ }^{3}$ The data for Site 592 are presented and discussed in detail in the context of the results for Sites 593 and 594 , because the sediment records of these three sites are controlled mainly by the tectonic evolution of the New Zealand islands (Robert et al., this vol.). However, the paleoenvironmental history of the area near Site 592 was influenced by eolian and oceanographic processes characteristic of the evolution at the central Lord Howe Rise region that is discussed in this paper. Thus, some overlapping in the discussion of results from Site 592 is inevitable.
}

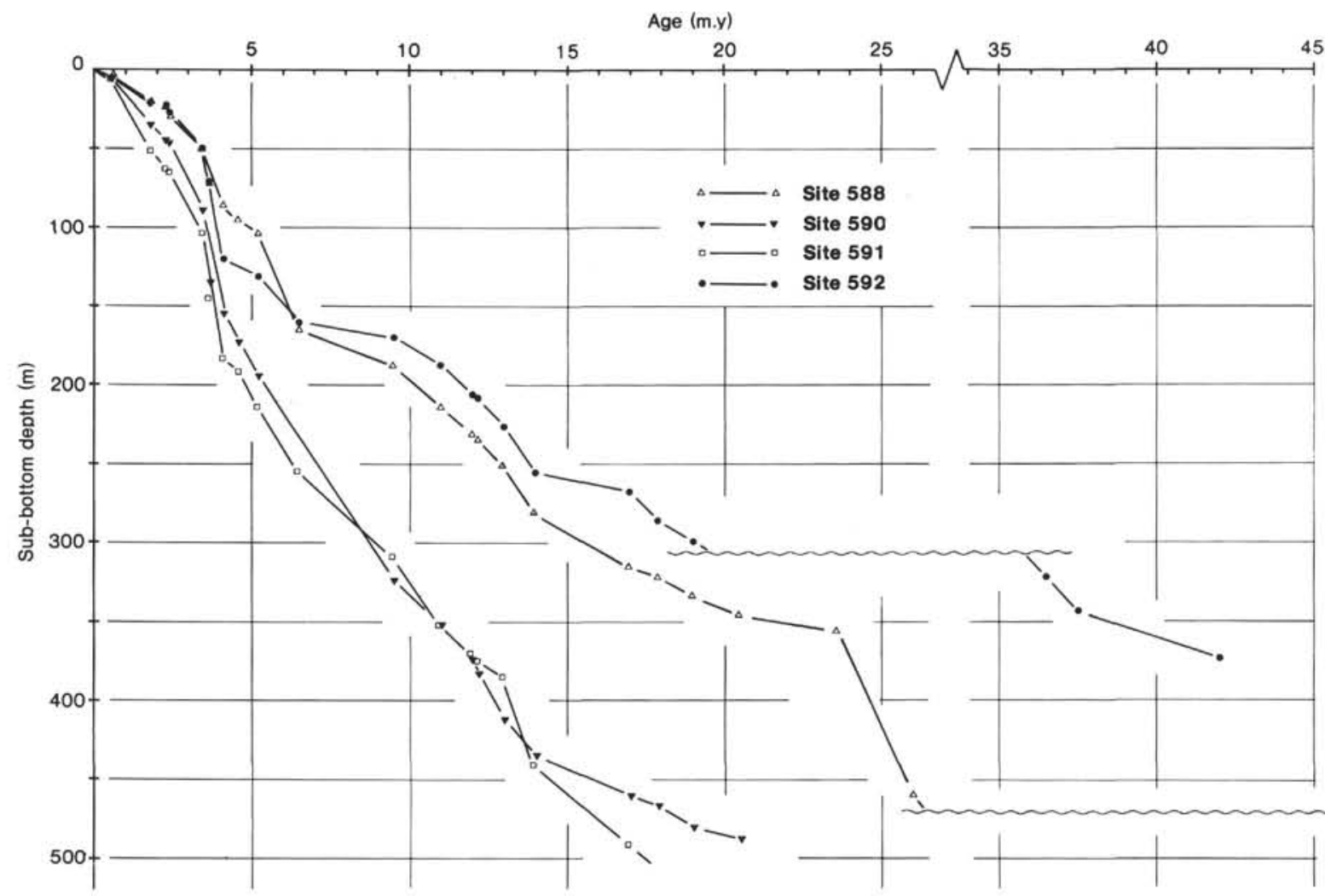

Figure 3. Linear sedimentation rates of bulk sediments at Sites $588,590,591$, and 592 according to the nannofossil biostratigraphy (Lohman, this vol., and Martini, this vol.). 


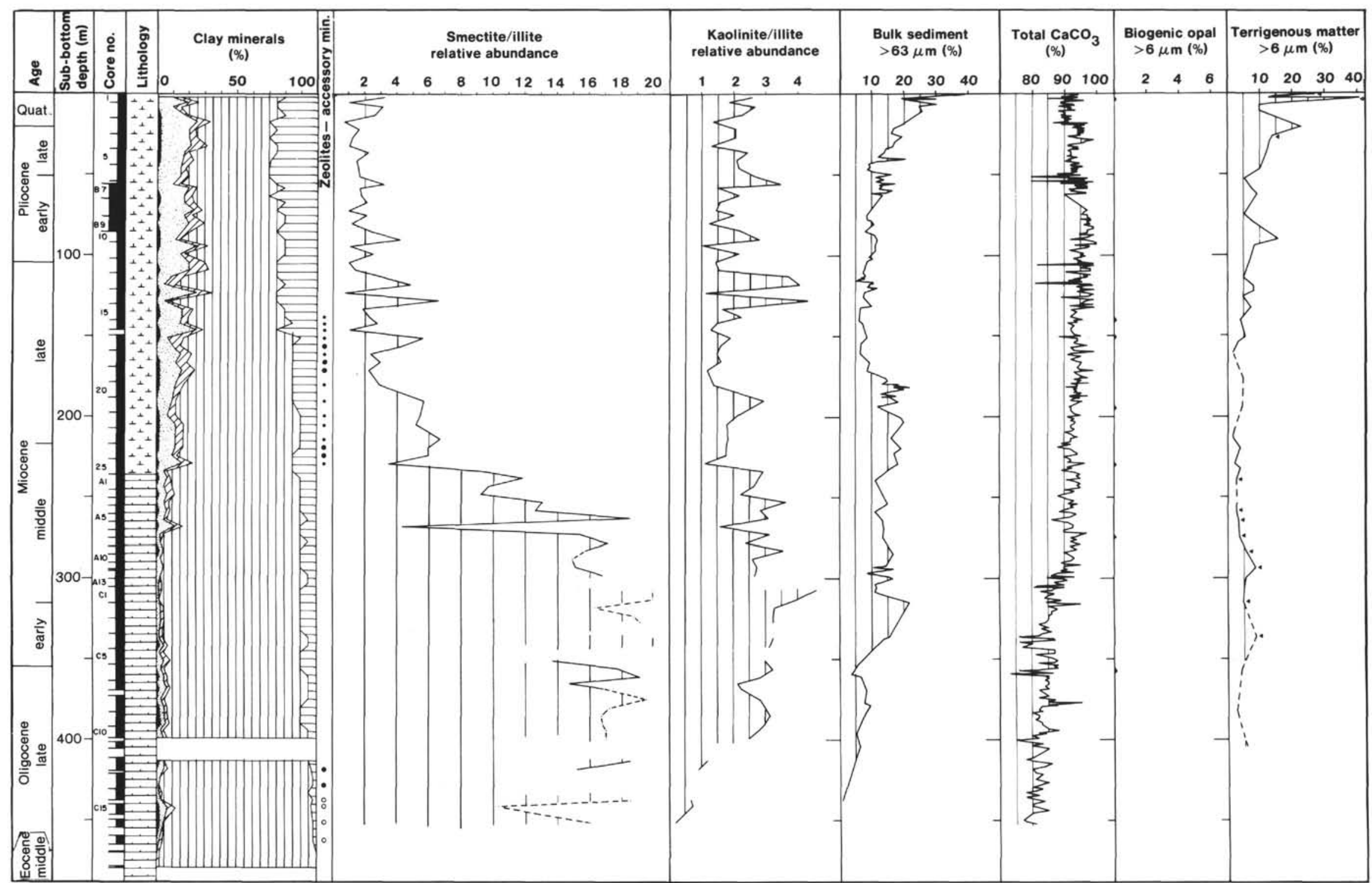

LITHOLOGY : 迹N Nannotossil ooze.

Nannofossil chalk.

Clay Minerals:

Chlorite

Abundan

ZIDS Mixed-lay

Kaolinite

Accessory Minerals: - Rare Common - Abundant oVery abundant

Figure 4. Site 588 results. Carbonate concentration values of bulk sediment samples are shipboard data (determined by carbonate bomb; see site chapter, this vol.), supplemented by the author's data of $138 \mathrm{CaCO}_{3}$ measurements. Contents of biogenic opal and terrigenous matter are percentages of the carbonate-free sediment fraction $<63 \mu \mathrm{m}$. Solid triangles indicate samples with amounts of volcanic glass. Letters A, B, C before core number indicate Holes 588A, B, C, respectively. 


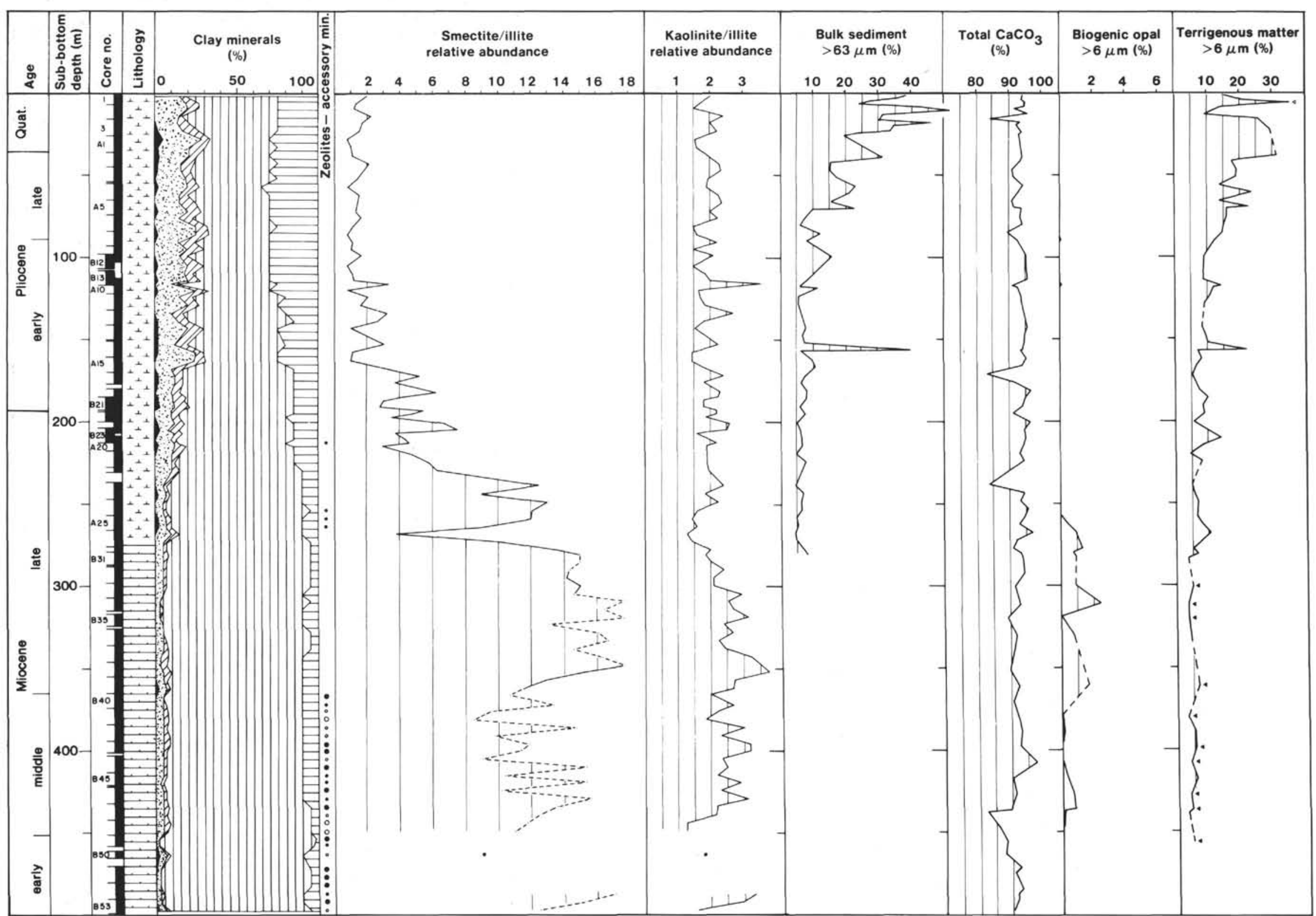

Figure 5. Site 590 results. For explanation of symbols see Figure 4 . Contents of biogenic opal $>6 \mu \mathrm{m}$ and terrigenous matter $>6 \mu \mathrm{m}$ in percentages of the carbonate-free sediment fraction $<63 \mu \mathrm{m}$. 


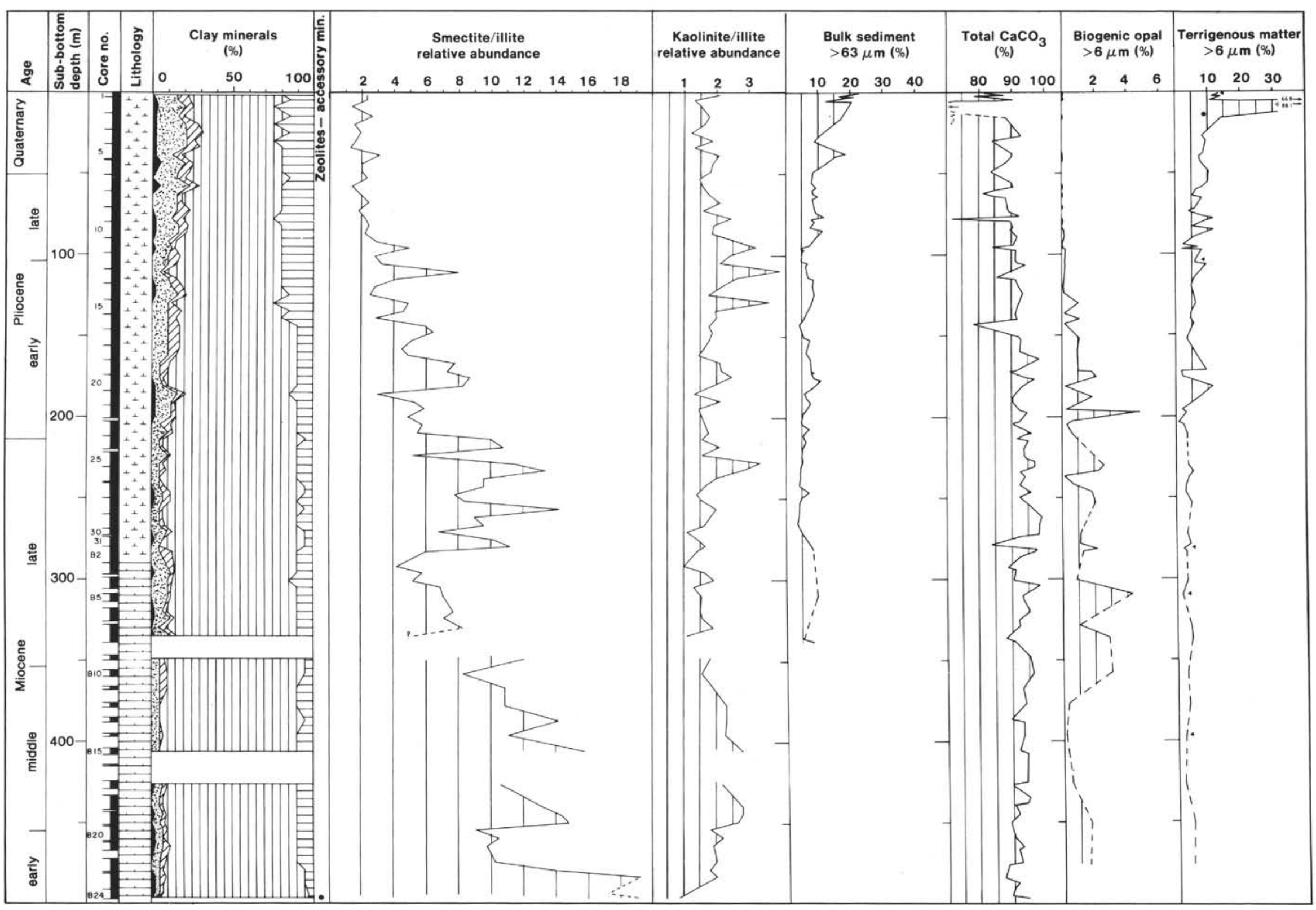

Figure 6. Site 591 results. For explanation of symbols see Figure 4. Content of biogenic opal $>6 \mu \mathrm{m}$ and terrigenous matter $>6 \mu \mathrm{m}$ in percentages of the carbonate-free sediment fraction $<63 \mu \mathrm{m}$. 


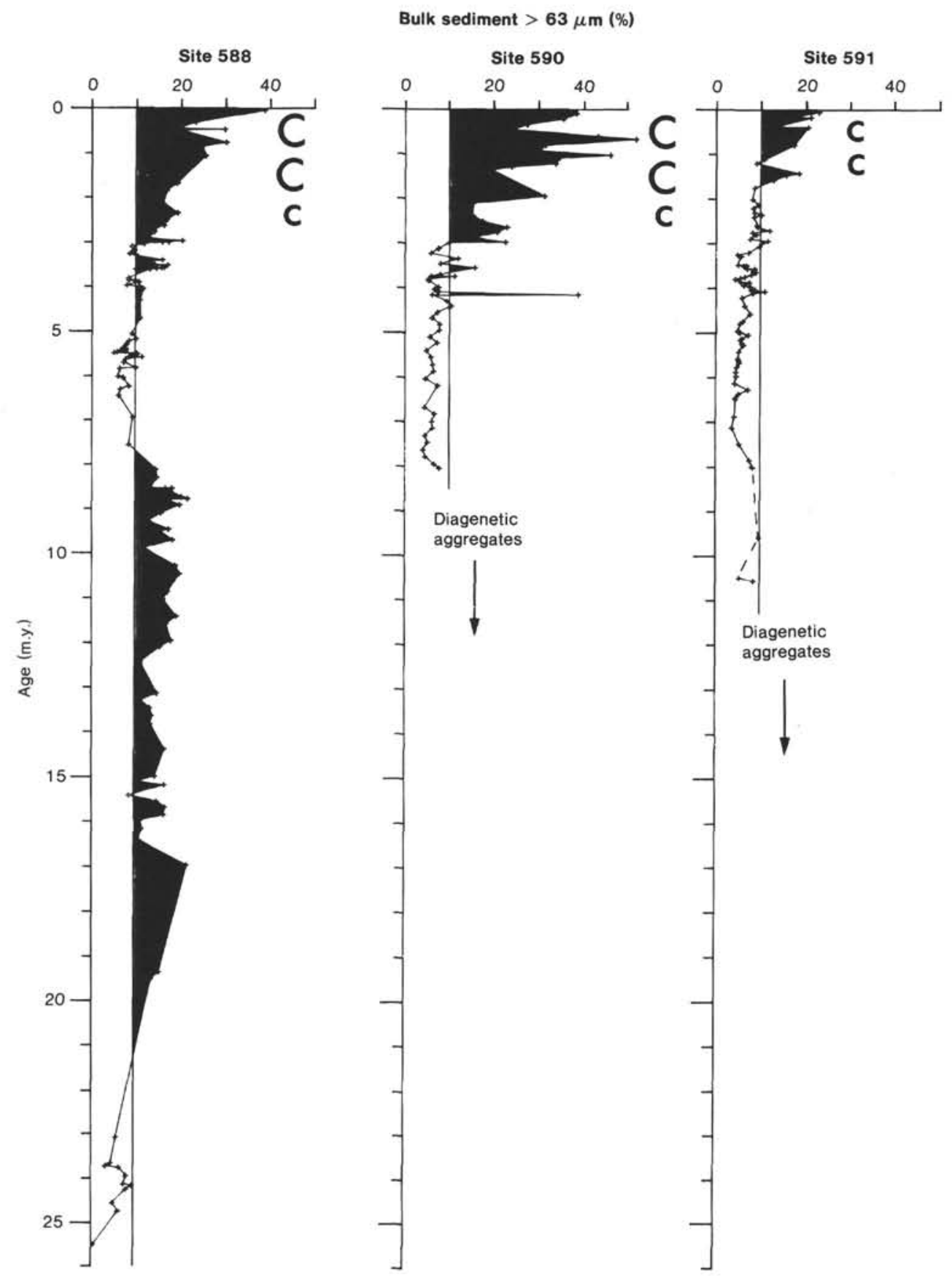

Figure 7. Percentages of sediment coarse fraction $>63 \mu \mathrm{m}$. "C" indicates intervals with a distinct coarsening of the bulk sediment fractions, interpreted as winnowing of the fine fraction by increased ("c") or strongly increased ("C") currents (cf. Fig. 9).

\section{Calcium Carbonate Content}

In general, all Leg 90 Sites at the Lord Howe Rise are characterized by high carbonate contents. The Neogene sediment sequences usually consist of more than about $90 \%$ calcium carbonate (Figs. 4, 5, and 6). Only in the late Oligocene to early Miocene of Site 588 are lower values of 75 to $90 \% \mathrm{CaCO}_{3}$ observed (Fig. 4 ; for detailed investigations of short-term and long-term cyclic variations of $\mathrm{CaCO}_{3}$, see Gardner, this vol.).

\section{Clay Minerals}

Smectites ( 40 to $100 \%$ ) are the dominant clay minerals at Sites 588, 590, and 591 (Figs. 4, 5, and 6). Fleecy particles, generally pedogenic, are often abundant in recent sediments and become sparse in older sediments. Fine laths, transparent and brittle, sometimes associated in geometrical figures, are rarely present in Quaternary sediments but are very abundant in Miocene and Paleogene sediments (Plate 1). As in the New Zealand 
section of the Tasman Sea, fleecy particles and very fine laths correspond to different morphological types of smectites. These laths were formed during in situ recrystallization of smectites within the interstitial sedimentary environment, without significant chemical or mineralogical change (Holtzapffel et al., in press). On the Lord Howe Rise, as around New Zealand, recrystallization processes occur in sediments which are characterized by high sedimentation rates and where the terrigenous components are highly diluted by the biogenic elements (Robert et al., this vol.). There is no apparent modification in the recrystallization of the smectites at Sites 590 and 591 during the early Miocene, when recrystallization of the carbonates began. Nor is there any change in the S/I index that can be related to the beginning and the development of the recrystallization of the smectites. This phenomenon does not influence the paleoenvironmental significance of the clay minerals. Thick-lathed particles, as well as globular packs of fine laths (Plate 1) are also present. These morphological types of particles become more abundant in levels where volcanic glass is present and in the vicinity of greenish gray laminae of devitrified volcanic ash (site chapters, this vol.) and probably correspond to smectites formed during alteration processes of volcanic products. The scarcity of these particles means that this mechanism is not a major contributor to smectite genesis in the sediments from the Lord Howe Rise.

Smectites are accompanied by kaolinite $(0-35 \%)$, illite $(0-25 \%)$, irregular mixed-layer clays $(0-10 \%)$, and chlorite $(0-5 \%)$. During the Neogene, illite, irregular mixed-layer clays, and kaolinite increase gradually, whereas the abundance of smectite decreases (Fig. 4, 5, and 6 ). Electron micrographs show the presence of very long and flexuous elements. Rarely present, these fibers are sometimes associated in clusters (Plate 1). They are very similar to palygorskite or sepiolite particles but are not abundant enough to be determined by X-ray diffraction.

The clay mineral assemblages suggest that the sediments of Sites 588,590 , and 591 can be separated into the following major intervals:

\section{Middle Eocene and late Oligocene}

During the middle Eocene, smectite is the only clay mineral found in the sediments of Site 588. Illite $(5 \%)$ and kaolinite $(10 \%)$ are first recorded in the late Oligocene (Fig. 4).

\section{Early Miocene to early Pliocene}

Illite and kaolinite both show a further increase from $5 \%$ in the early Miocene to $30 \%$ in the early Pliocene (Figs. 4, 5, and 6). Mixed-layer minerals occur in trace amounts up to about $10 \%$. This time interval is characterized by distinct changes in the relative abundances of clay minerals (S/I, K/I ratios; Figs. 4, 5, 6, and 8). These changes are not synchronous at all sites. A decrease in the S/I ratio near the early/middle Miocene boundary ( $15 \mathrm{~m} . \mathrm{y}$.) is paralleled by $\mathrm{K} / \mathrm{I}$ minima at Sites 588 and 590 . A drastic change in the S/I ratios from values between 19 and 16 to values of about 4 occurs in sediments deposited during the middle Miocene at Site
588 and during the late Miocene at Sites 590 and 591 (Figs. 4-6). These major changes coincide with lesser decreases in the $\mathrm{K} / \mathrm{I}$ ratios (Figs. 4, 5, 6, and 8). At site 591 , the early Miocene decrease in $\mathrm{S} / \mathrm{I}$ is followed by an increase of the S/I ratio to about 14 in the latest Miocene, followed by a decrease to 2 during the early Pliocene (Figs. 6 and 8). More or less distinct maxima in the $\mathrm{K} / \mathrm{I}$ ratios are observed in all three sites near 5.5 and 3.5 m.y. (Figs. 4-6).

\section{Pliocene to Quaternary}

The youngest sediment sections at all three sites are characterized by clay mineral assemblages of smectite (40-50\%), kaolinite (20-35\%), and illite (about 20\%) (Figs. 4-6). The S/I ratios show relatively constant, low mean values of 1.5 to 2 (Fig. 8). The change to these low $\mathrm{S} / \mathrm{I}$ ratios is asynchronous, like the middle Miocene change, and occurs at Site 588 near 5.5, at Site 590 near 4, and at Site 591 near 3 m.y ago (Fig. 8).

\section{Composition, Grain Sizes, and Flux Rates of the Carbonate-free Sediment Fraction}

The main proportion of the carbonate-free silt fraction is siliciclastic. Biogenic opal is also abundant in several core intervals (Figs. 5 and 6).

The content of biogenic opal in the 6- to $63-\mu \mathrm{m}$ fraction is negligible in the carbonate-free sediment fractions of Site 588 (Fig. 4). Significant concentrations of biogenic opal are observed at Sites 590 and 591 during the time interval between 14 and $3.6 \mathrm{~m}$.y. These concentrations are clearly greater in the sediments deposited at $2130 \mathrm{~m}$ water depth than in those deposited at $1300 \mathrm{~m}$ (Figs. 5 and 6).

Yellowish volcanic glass shards are observed in the Neogene sections prior to $9 \mathrm{~m}$.y. and are more common in the northern than in the southern Lord Howe Rise region (Fig. 9; Robert et al., this vol.). A further distinct volcanic event is indicated by a high content of light volcanic glass near 0.4 m.y. ago (Fig. 9). However, both the amount and the grain size of the Quaternary volcanic glass particles decrease toward the north, unlike the early and middle Miocene glass shards.

The grain size of the terrigenous silt fraction has remained almost unchanged in all sites of the Lord Howe Rise during the last 15 m.y. (compare histograms in Fig. 10). In general, the grain-size modes lie near $18 \mu \mathrm{m}$. The similarity of the modes may suggest the same provenance region for the terrigenous silt-sized matter (see Dauphin, 1980; Sarnthein et al., 1982), that is probably the Australian continent by analogy to the recent and subrecent supply regime (Healy, 1970; Glasby, 1971; Thiede, 1979). The grain size of volcanic glass shards observed in middle Miocene and Quaternary time intervals is significantly coarser than the grain size of the terrigenous matter supplied from the Australian continent: the modes lie near $40 \mu \mathrm{m}$ (Fig. 10). The amount of terrigenous medium- and coarse-sized silt (i.e., $>6 \mu \mathrm{m}$ ) varies between 2 and $10 \%$ at all three sites prior to 4 m.y. Between 3 and $4 \mathrm{~m} . \mathrm{y}$, the $>6 \mu \mathrm{m}$ fraction at Sites 588 and 590 increases to more than $10 \%$, reaching maximum values of $30 \%$ at Site 590 near 2 m.y. (Fig. 9; Robert et al., 


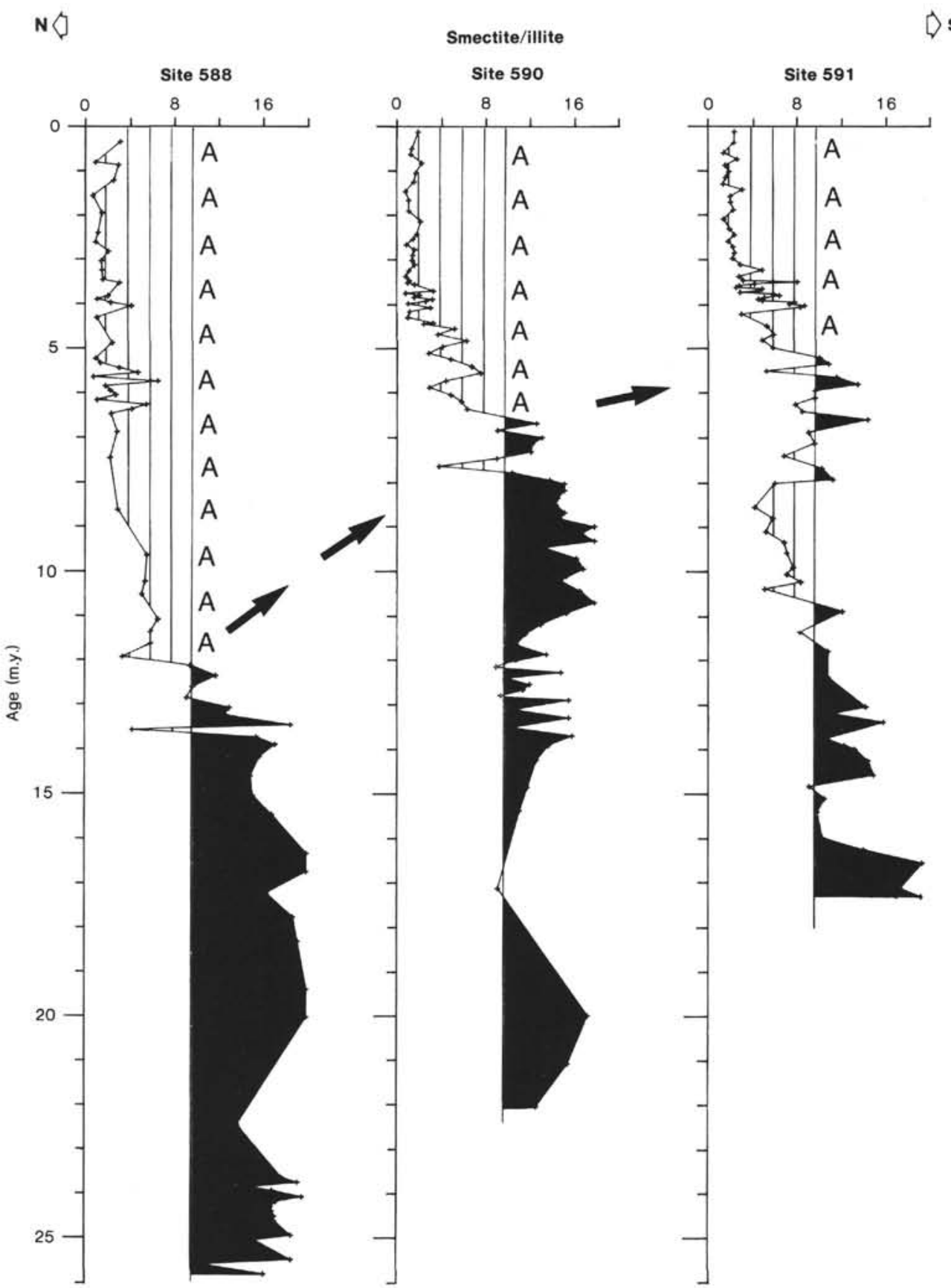

Figure 8. Smectite/illite (S/I) ratios of clay mineral assemblages at the Lord Howe Rise. Black arrows mark the boundary between dominantly high and extremely low $\mathrm{S} / \mathrm{I}$ ratios. The latter are interpreted as representative of dominantly arid climate ("A"). Furthermore, those arrows should indicate the southward expansion of Australian deserts during middle and late Miocene time (cf. Fig. 12).

this vol.). At Site 591, the $>6 \mu \mathrm{m}$ values are significantly lower. The maximum values near 0.4 m.y. ago at all three sites mark a coarse-sized ash layer (Fig. 9).

Changes in the mass accumulation rates of the carbonate-free sediment fraction mainly reflect variations in the terrigenous sediment supply. Maximum MART are recorded in the latest Oligocene (up to $1.5 \mathrm{~g} \cdot \mathrm{cm}^{-2}$ $\left.10^{-3} \mathrm{y}^{-1}\right)$. A drastic decrease of the MART occurs at Site 588 near the Oligocene/Miocene boundary (Fig. 11). This decrease resulted from a change in the LSR (Fig. 3) so abrupt that it is possibly an artefact of the time scale applied. The earliest Miocene is characterized by very low MART $\left(0.05-0.08 \mathrm{~g} \cdot \mathrm{cm}^{-2} 10^{-3} \mathrm{y}^{-1}\right)$, followed by a slight increase to about $0.2 \mathrm{~g} \cdot \mathrm{cm}^{-2} 10^{-3} \mathrm{y}^{-1}$ near 20 m.y. ago (Site 588, Fig. 11). A distinct maximum of MART of up to $0.5 \mathrm{~g} \cdot \mathrm{cm}^{-2} 10^{-3} \mathrm{y}^{-1}$ at Site $588,0.25$ $\mathrm{g} \cdot \mathrm{cm}^{-2} 10^{-3} \mathrm{y}^{-1}$ at Site 590 , and $0.7 \mathrm{~g} \cdot \mathrm{cm}^{-2} 10^{-3}$ $\mathrm{y}^{-1}$ at Site 591 occurs at $14-13$ m.y. (Fig. 11). Values between 0.2 and $0.4 \mathrm{~g} \cdot \mathrm{cm}^{-2} 10^{-3} \mathrm{y}^{-1}$ dominate at Sites 590 and 591 between 11 and 4 m.y. ago (Fig. 11). At Site 


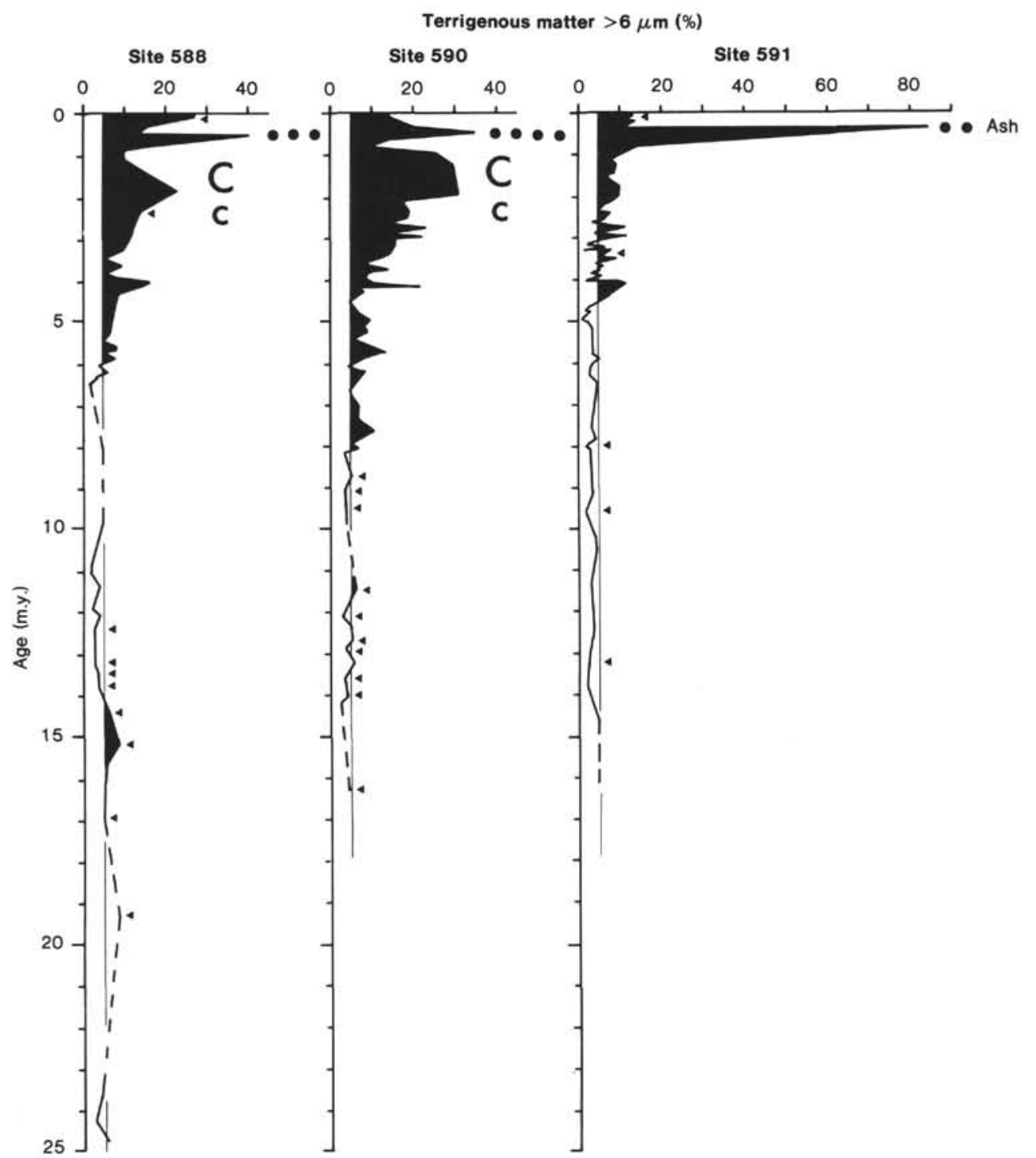

Figure 9. Terrigenous sediment fraction $>6 \mu \mathrm{m}$ (i.e., carbonate-free sediment fraction $>6 \mu \mathrm{m}$ minus biogenic opal $>6 \mu \mathrm{m}$ ) in percentages of the carbonate-free sediment fraction $<63 \mu \mathrm{m}$. Triangles indicate samples with amounts of volcanic glass. Black dots mark a distinct Quaternary ash layer observed in all three sites. The increased $>6 \mu \mathrm{m}$ values during the last $3 \mathrm{~m} . \mathrm{y}$. are probably caused by intensified oceanic currents ("C"), resulting in winnowing of the fine fraction (cf. Fig. 7).

588 the MART gradually decreases between 13 and 9.5 m.y., and values of less than $0.1 \mathrm{~g} \cdot \mathrm{cm}^{-2} 10^{-3} \mathrm{y}^{-1} \mathrm{oc}-$ cur between 9.5 and 6.5 m.y. ago. Further distinct maxima of MART are observed at Site 588 near 6 and 4 m.y. ago. The latter maximum is also recorded at Sites 590 and 591 (Fig. 11, more than $1 \mathrm{~g} \cdot \mathrm{cm}^{-2} 10^{-3} \mathrm{y}^{-1}$ ). The last 3 m.y. are characterized by reduced MART at the shallower Sites 588, 590, and 592, whereas the MART at the deeper Site 591 continue to be relatively high (but lower than those at $4 \mathrm{~m}$.y.) (Fig. 11). In the uppermost sediment sequences of all four sites (last 500,000 yr.) the MART values are low, varying from 0.04 to $0.2 \mathrm{~g} \cdot \mathrm{cm}^{-2}$ $10^{-3} \mathrm{y}^{-1}$, which is similar to the modern rates of eoliandust accumulation in the southwest Pacific $(0.08 \mathrm{~g}$. $\mathrm{cm}^{-2} 10^{-3} \mathrm{y}^{-1}$; according to Windom [1969], using the porosity and wet-bulk density data of the near-surface samples of the Lord Howe Rise sites). This suggests that most of the terrigenous sediments at the Lord Howe Rise have been supplied by winds.

\section{NEOGENE EVOLUTION OF \\ PALEOENVIRONMENTS AT THE CENTRAL LORD HOWE RISE}

Table 2 summarizes the Neogene evolution of climate and oceanic circulation in the southwest Pacific region that can be deduced from the terrigenous-sediment fraction at the Lord Howe Rise.

\section{Oligocene}

During the latest Oligocene, the dominance of pedogenic smectite in the northern Lord Howe Rise area suggests predominantly warm climatic conditions with al- 


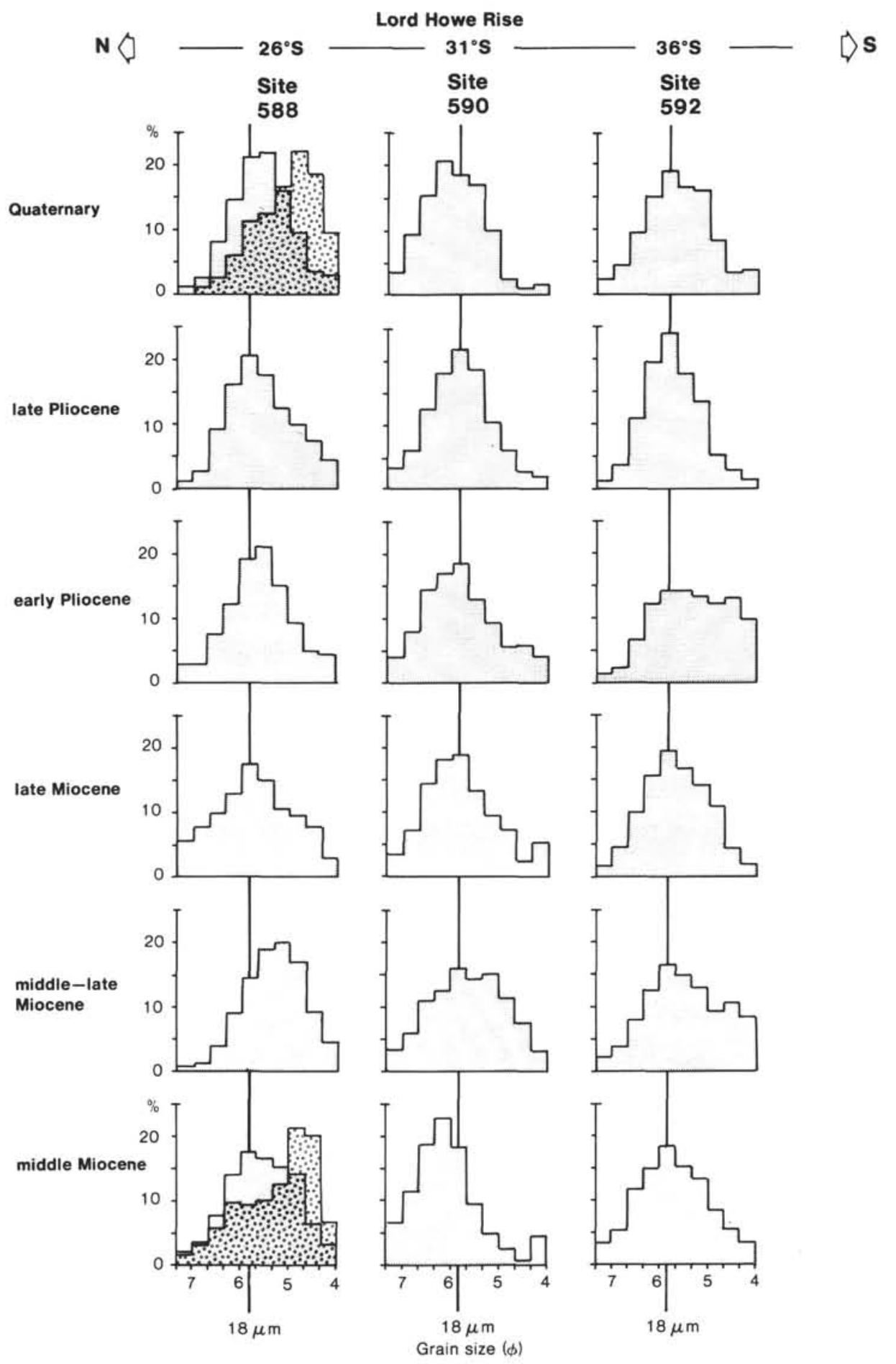

Figure 10. Typical grain-size distributions of the carbonate-free silt fractions from the Lord Howe Rise Sites for different time intervals, figured as histograms. Site 588 histograms defined by open circles (middle Miocene and Quaternary) show grain-size distributions of samples rich in volcanic glass.

ternating periods of humidity and aridity in a source area characterized by low relief (i.e., Australia). This climatic pattern is similar to that found at present in southern Morocco (Paquet, 1969) and the Chad Basin (Gac, 1979). The gradual increase of the $\mathrm{K} / \mathrm{I}$ ratio during the Oligocene at Site 588 (Fig. 4) may have been caused by the gradual northward drift of the Indo-Australian Plate toward lower latitudes, resulting in an increased admix- ture of kaolinite from tropical areas by southward-flowing oceanic currents or by tropical cyclones. High mass accumulation rates of terrigenous, mainly clay-sized matter at Site 588 (Fig. 11), if not an artefact of the time scale applied (see above), are possibly also related to stronger southward-flowing surface currents in the Tasman Sea during the Oligocene (Kennett, 1978b). The lower percentages of $\mathrm{CaCO}_{3}$ during the late Oligocene (Fig. 4) 


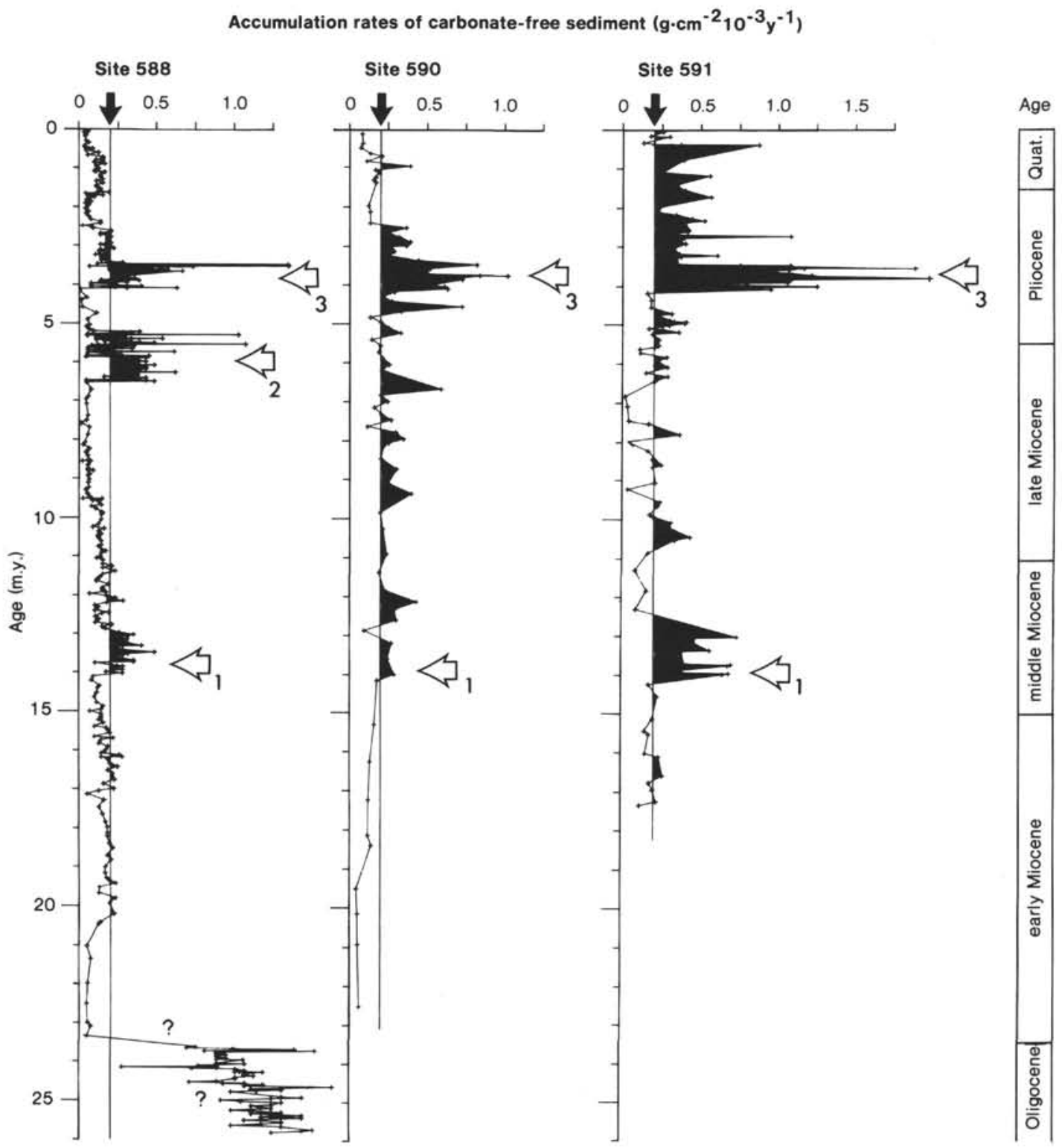

Figure 11. Mass accumulation rates of the carbonate-free (mainly terrigenous) sediment fraction (MART) at the Lord Howe Rise during Neogene times. Black arrows mark the maximum value of recent accumulation rates of terrigenous matter recorded in the Pacific $\left(0.01\right.$ to $0.2 \mathrm{~g} \cdot \mathrm{cm}^{-2} 10^{-3} \mathrm{y}^{-1}$; Folger, 1978). Open arrows indicate (1) the first occurrence of distinct maximum values of MART in the middle Miocene, (2) distinct late Miocene maximum of MART at Site 588, and (3) extreme maxima of MART in the early Pliocene. The change of the MART at Site 588 near the Oligocene/Miocene boundary is so abrupt that it is possibly an artefact of the time scale applied(?).

may be the result of dilution by this increased terrigenous supply. The reduction in mass accumulation rates at the Oligocene/Miocene boundary (Fig. 11) coincided with a change of circulation regime in the Tasman Sea. The southward-flowing currents dominating during the Oligocene decreased in intensity. The intensity of the northward-flowing bottom waters through the Tasman Sea also decreased as the western boundary current became strongly established east of New Zealand (Kennett, 1977, 1978b; cf. Robert et al., this vol.).

\section{Early and Middle Miocene}

An increase in explosive volcanism in the early and middle Miocene is suggested by the abundance of vol- canic glass in sediments on the Lord Howe Rise (Fig. 9). At the same time, higher abundances of greenish gray laminae, defined as volcanic ash or diagenetically altered volcanic ash (Gardner et al., this vol.), as well as of volcanogenic smectite are observed. Volcanic glass occurs more frequently in samples at the northern sites than at the southern sites. This fact, along with the coarseness of the volcanic glass shards, suggest a high-energy transport system from north to south like, for example, the tropical cyclones which today reach wind speeds exceeding Beaufort force 9, that is, 20 to $24 \mathrm{~m} / \mathrm{s}$ (Ramage, 1970). The suggestion that volcanic ash may have been supplied by tropical cyclones from the north is further supported by the fact that the volcanic glass in the Lord 
Table 2. Major changes in paleoenvironment and climatic events and their signals in the sediments at the Lord Howe Rise.

\begin{tabular}{|c|c|c|c|c|c|}
\hline & & Signals in the sediment & Interpretations & Major events & $\begin{array}{l}\text { Plate tectonic drift } \\
\text { and related events }\end{array}$ \\
\hline (15) & $\begin{array}{l}x \\
x \\
x \\
x \\
x \\
x \\
x \\
x \\
x \\
x \\
x \\
x \\
x \\
x \\
x \\
x \\
x \\
x \\
x \\
x \\
x \\
x \\
x \\
x \\
x \\
x\end{array}$ & $\begin{array}{l}\text { Abundant light volcanic glass } \\
\text { (decrease of both thick- } \\
\text { ness of ash layer and } \\
\text { grain size from Site } 591 \\
\text { to Site } 588 \text { ) } \\
\text { Decrease of S/I ratios to } \\
\text { Quaternary values; } \\
\text { coarsening of grain sizes } \\
\text { of terrigenous and } \\
\text { carbonate sediment } \\
\text { fractions } \\
\text { Minimum values of S/I } \\
\text { ratios and K/I ratios; } \\
\text { increased MART }\end{array}$ & $\begin{array}{l}\text { Dominantly arid } \\
\text { climate in much } \\
\text { of Australia; } \\
\text { increased oceanic } \\
\text { intermediate- } \\
\text { water circulation } \\
\text { Expansion of deserts } \\
\text { and semideserts } \\
\text { in Australia }\end{array}$ & $\begin{array}{l}\text { Quaternary volcanism on } \\
\text { North Island of New } \\
\text { Zealand (Nelson and } \\
\text { Hume, 1977) } \\
\text { Development of major } \\
\text { Arctic ice sheets } \\
\text { (Shackleton and } \\
\text { Kennett, 1975; Shack- } \\
\text { leton and Opdyke, } \\
\text { 1977) } \\
\text { Expansion of Antarctic ice } \\
\text { sheets (Shackleton and } \\
\text { Kennett, 1977; Mercer } \\
\text { and Sutter, 1982); } \\
\text { increased aridity in } \\
\text { South Australia } \\
\text { (Kemp, 1978) } \\
\text { Major cooling in high } \\
\text { northern latitudes } \\
\text { (Denton and Arm- } \\
\text { strong, 1969; Mudie } \\
\text { and Helgason, 1983). } \\
\text { Buildup of AA ice } \\
\text { sheets essentially } \\
\text { complete (Shackleton } \\
\text { and Kennett, 1975) } \\
\\
\text { Development of major } \\
\text { Antarctic ice sheets } \\
\text { (Shackleton and } \\
\text { Kennett, 1975; Wood- } \\
\text { ruff et al., 1981); } \\
\text { desertification in } \\
\text { northern parts of } \\
\text { Australia (Kemp, } \\
\text { 1978) }\end{array}$ & $\begin{array}{l}\text { Northward drift of the } \\
\text { Indo-Australian } \\
\text { Plate into drier } \\
\text { climatic belts }\end{array}$ \\
\hline
\end{tabular}

Note: MART $=$ mass accumulation rates of terrigenous matter; $x=$ interval characterized by the occurrence of yellowish volcanic glass.

Howe Rise sediments occurred contemporaneously with tectonic and volcanic activities in the Melanesian and New Hebrides islands (Crook and Belbin, 1978; cf. Nelson et al., this vol.). New Zealand may also have been a source area of volcanic ash, because volcanic activity was prevalent on the North Island of New Zealand during those times (Crook and Feary, 1982). However, this explanation is less probable for the northern Sites on the Lord Howe Rise, because the transport energy of the surface winds needed to carry dust from New Zealand (Fig. 1) would be unrealistically high for the long-distance transport of coarse-silt-sized grains to Site 588 (the downwind distance from New Zealand to Site 588 exceeds $2500 \mathrm{~km}$ ).
The distinct increase of illite at Site 588 during the middle Miocene near 12.5 m.y. (Fig. 8) suggests increased desertification in the source area, the northern to central parts of Australia (Figs. 8 and 12). Southern Australia may still have been dominated by alternating humid and semiarid climatic conditions, however, as is indicated by the continuously high amounts of pedogenic smectite at the more southern Site 590 (Figs. 8, 12). Increased desertification in northern and northwestern areas of Australia at this time was also inferred from palynological data (Kemp, 1978) and from investigations of ancient drainage systems (van de Graaff et al., 1977). The expansion of aridity in northern Australia may have been caused by both the northward drift of the Indo- 

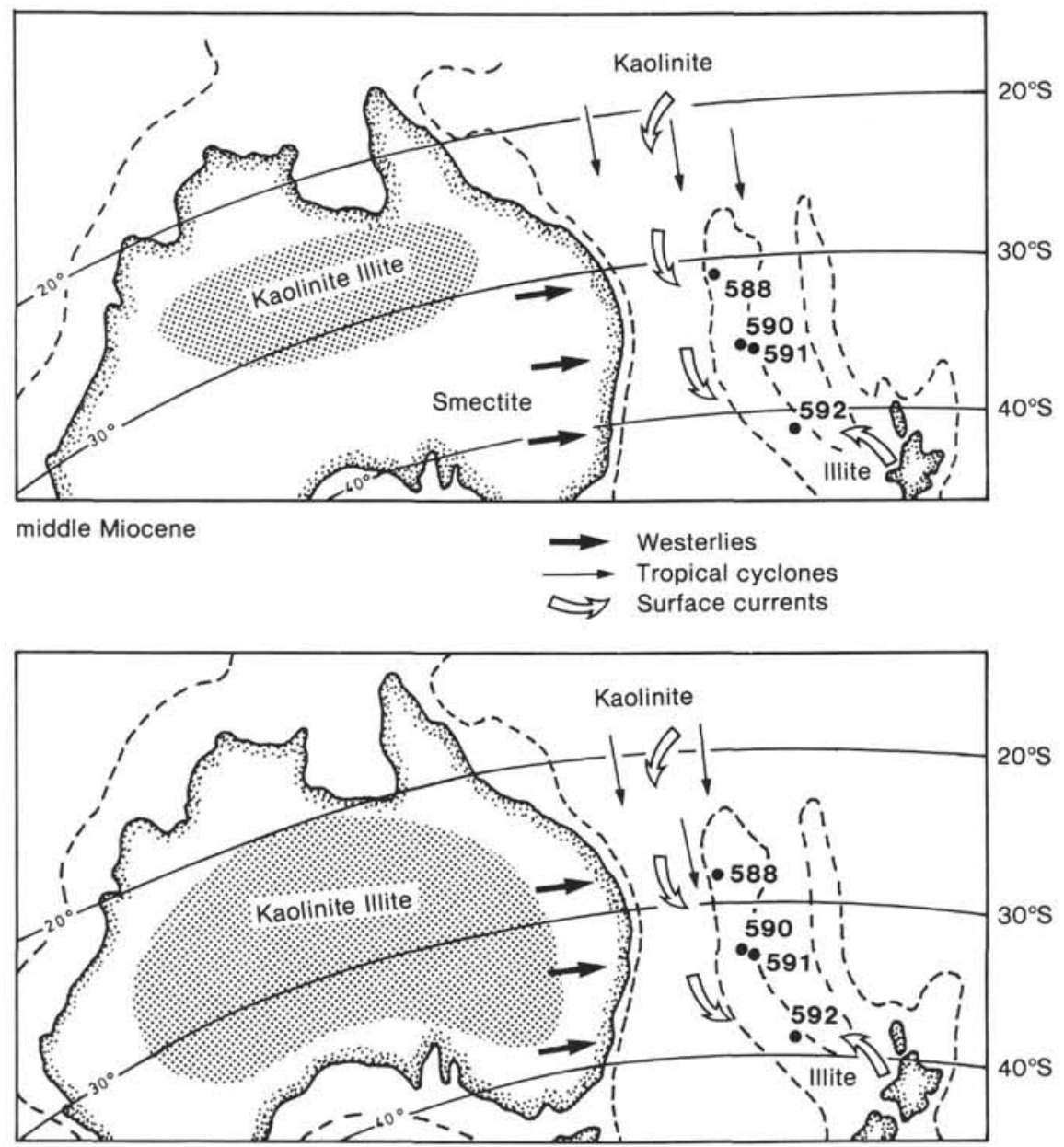

late Miocene

Figure 12. Interpretation of clay mineral data of Miocene sediments from the Lord Howe Rise. Paleogeography from Kemp (1978), according to Hayes and Ringis (1973) and Weissel and Hayes (1972). For atmospheric and oceanic circulation see Figure 1. Dashed line approximates the $3000 \mathrm{~m}$ isobath (Kemp, 1978).

Australian Plate into a drier climatic belt and the development of major Antarctic ice sheets during that time (Shackleton and Kennett, 1975; Kennett, 1977; Savin et al., 1981; Woodruff et al., 1981). The transition from a dominantly humid climate to a more semiarid and arid climate resulted in a reduced vegetation cover and increased availability of eolian sediments in the source area. This transition is indicated by increased flux rates of terrigenous matter at the Lord Howe Rise near 14 to 13 m.y., that is about $1 \mathrm{~m} . \mathrm{y}$. before maximum aridity developed in northern and central Australia (Fig. 11). Concomitant with the buildup of the Antarctic ice sheets, upwelling at the Subtropical Divergence Zone (Burkov, 1966; Knox, 1970) may have intensified, increasing the fertility of surface waters and generating greater productivity, which is reflected in increased deposition of biogenic opal at Sites 590 and 591 between 14 and 3.6 m.y. ago (Figs. 5 and 6).

The distinct S/I minimum at Site 591 near 9 m.y. was not recorded at nearby Site 590 (Fig. 8). The change in the clay mineral assemblage at Site 591 may have been caused by an increased admixture of illite from eastern or southeastern regions by oceanic currents in water depths below $1300 \mathrm{~m}$. Because Site 591 is not located in the same water mass as the shallower Sites 588 and 590 , it may be influenced more by Antarctic or New Zealand sources than the other two sites. This paleoenvironmental change coincided with a phase of major cooling in northern high latitudes (Denton and Armstrong, 1969; Mudie and Helgason, 1983). The buildup of the middle to late Miocene Antarctic ice cap was essentially complete near 9 m.y. (Shackleton and Kennett, 1975; Kennett, 1978a).

\section{Late Miocene to Early Pliocene}

The sharp decrease of the S/I index at Site 590 during the late Miocene can be interpreted as an increased input of illite, eroded from central Australia as the desert areas expanded southward (Figs. 8, 12). Extremely low S/I ratios, similar to those of Pleistocene time, occurred at all three sites during the latest Miocene (Site 588) to early Pliocene (Sites 590 and 591) (Fig. 8). They suggest a major expansion of the Australian deserts and semideserts, a view which is also supported by land data. 
From palynological data, Kemp (1978) has deduced a general increase of aridity in central Australia as well as in the Murray and Gippsland basins. In addition, Locker and Martini (this vol.) recorded an increase in the supply of opal phytoliths to the Lord Howe Rise, interpreted as indicating expanded aridity in Australia. This change in paleoenvironment was probably related to the maximum buildup of Antarctic ice masses during latest Miocene-earliest Pliocene times (Kennett et al., 1975, Shackleton and Kennett, 1975; Mercer and Sutter, 1982). Maximum accumulation rates of terrigenous matter are observed at all sites at the Lord Howe Rise near 4 m.y. ago (Fig. 11), just after the phase of maximum Antarctic glaciation and aridity in Australia, but contemporaneously with a major cooling trend in the southwest Atlantic sector of the Southern Ocean (Ciesielski and Wise, 1977). This increase of eolian sediment supply from Australian deserts toward the Lord Howe Rise (i.e., Southern Hemisphere) occurs about 0.8 m.y. earlier than a similar increase of eolian sediment supply from the Saharan desert toward the northeast Atlantic (i.e., Northern Hemisphere; Stein, 1985a).

\section{Pliocene to Quaternary}

A major change in paleoceanography in the southwest Pacific near 3 m.y. coincided with the development of major ice sheets in the Northern Hemisphere (Shackleton and Kennett, 1975; Shackleton and Opdyke, 1977; Keigwin, 1979, 1982; Shackleton et al., 1984) and continental evidence of glaciation in southern South America (Mercer, 1976). The extremely low accumulation rates (Fig. 11) and the concomitant coarsening of both bulk sediment (Fig. 7) and the terrigenous sediment fractions in water depths between $1100 \mathrm{~m}$ and $1530 \mathrm{~m}$ (Fig. 9) suggest winnowing by intensified currents at these water depths during the last $3 \mathrm{~m} . \mathrm{y}$. This may indicate an intensified advection of water masses in intermediate water depths (probably the East Australian Current and/or Antarctic Intermediate Water). Thus, the grain size of the terrigenous sediments at Sites 588 and 590 allows no interpretation in terms of intensity of atmospheric circulation during that time. At Site 591, however, in water depths below the influence of the East Australian Current, the intermediate-water circulation was less enhanced (Figs. 7 and 9). At this site, the accumulation rates of terrigenous matter remained high through the Pliocene and Pleistocene (Fig. 11) and could be interpreted as continuously high eolian dust input to the central Lord Howe Rise and/or a supply of clay-sized material by deeper-water currents.

The low S/I ratios at all Leg 90 sites from the Lord Howe Rise during the last 3 m.y. may imply dominantly arid climatic conditions in large parts of Australia during late Pliocene and Quaternary times. The relatively high amounts of the terrigenous coarser-silt fraction at Site 591 (Fig. 9) may suggest enhanced atmospheric circulation during the last $4 \mathrm{~m} . \mathrm{y}$. It is interesting that increased atmospheric circulation and mass flux of dust were recorded in Northern Hemisphere eolian sediments from the North Pacific and northeast Atlantic about 0.8 m.y. later (Leinen and Heath, 1981; Rea and Harrsch,
1981; Rea and Janecek, 1982; Janecek and Rea, 1983; Stein, 1984, 1985a; Stein and Sarnthein, 1984a).

A conspicuous volcanic event was recorded at the Lord Howe Rise during Quaternary times. Distinct amounts of light volcanic glass occurred in the sediments of Sites 588,590 , and 591 near 0.4 m.y.; thickness of ash layers (site chapters, this vol.) and grain size of volcanic glass particles both decrease from south to north (Fig. 9). This pattern suggests that the volcanism was centered in southern regions. One possible source area is the North Island of New Zealand, where Nelson and Hume (1977) have reported Quaternary volcanism connected with the formation of the Taupo Graben and the Havre Trough.

\section{CONCLUSIONS}

1. Two processes were of major importance for the Neogene evolution of climate and oceanic circulation in the southwest Pacific: (1) the continued northward drift of the Indo-Australian Plate and (2) the development of the Antarctic ice sheets.

2. Desertification in Australia started in the northern parts of the continent near 14 m.y. and expanded southward during the late Miocene. Maximum phases of aridity coincided with major cooling events near $12,9,5$, and $3 \mathrm{~m} . \mathrm{y}$., as indicated by distinct minima of the S/I ratios. Accumulation rates of terrigenous sediments at the Lord Howe Rise increase during the transition from a dominantly humid to a more arid climate during the last $4 \mathrm{~m} . \mathrm{y}$., and during the last $3 \mathrm{~m}$.y. the climate of most of Australia has been dominated by aridity.

3. Upwelling at the Subtropical Convergence Zone may have been intensified between 14 and $3.6 \mathrm{~m} . \mathrm{y}$., resulting in increased productivity, as indicated by significant amounts of biogenic opal at Sites 590 and 591 .

4. Enhanced oceanic intermediate-water circulation during the last 3 m.y. is inferred from decreased accumulation rates and a coarsening of both bulk and terrigenous sediment fractions at Sites 588 and 590.

5. Periods of explosive volcanicity in the Southwest Pacific occurred between 21 and 9 m.y. and near 0.4 m.y., as is suggested by increased input of volcanic glass to the Lord Howe Rise sediments.

\section{ACKNOWLEDGMENTS}

We would like to thank Drs. H. Chamley and M. Sarnthein for critical discussions. For technical assistance, we gratefully acknowledge M. Acquaviva, T. Allert, J. P. Ripert, F. Sirocko, R. Spielhagen, and M. Stransky. We thank our reviewers T. Janecek and M. Leinen for their numerous constructive suggestions for improving the manuscript. Financial support for this study was provided by the Deutsche Forschungsgemeinschaft and the Centre National de la Recherche Scientifique (A.T.P. Géologie et Géophysique des Océans).

\section{REFERENCES}

Albertsson, K. J., 1981. Hambrey, M. J., and Harland, W. B. (Eds.), Earth's Pre-Pleistocene Glacial Record: Cambridge (Cambridge University Press), pp. 53-56.

Biscaye, P. E., 1965. Mineralogy and sedimentation of the recent deepsea clay in the Atlantic Ocean and adjacent seas and oceans. Geol. Soc. Am. Bull., 76:803-832.

Burkov, V. A., 1966. Structure and nomenclature of Pacific Ocean currents. Oceanology, 6:1-10.

Carlson, T., and Prospero, J. M., 1977. Saharan air outbreaks: meteorology, aerosols, and radiation. Rept. US GATE Central Progr. Workshop (NCAR), Boulder, Colorado, pp. 57-78. 
Chamley, H., 1979. North Atlantic clay sedimentation and paleoenvironment since the Late Jurassic. In Talwani, M., Hay, W., Ryan, W. B. F. (Eds.), Deep Drilling Results in the Atlantic Ocean: Continental Margins and Paleoenvironment. Am. Geophys. Un., Maurice Ewing Ser., 3:342-361.

1980. Clay sedimentation and paleoenvironment in the area of Daito Ridge (northwestern Philippine Sea) since the early Eocene. In Klein, G. deV., Kobayashi, K., et al., Init. Repts. DSDP, 58: Washington (U.S. Govt. Printing Office), 683-693.

Chamley, H., Maillot, H., Duée, G., and Robert, C., 1984. Paleoenvironmental history of the Walvis Ridge at the Cretaceous/Tertiary transition, from mineralogical and geochemical investigations. In Moore, T. C., Jr., Rabinowitz, P. D., et al., Init. Repts. DSDP, 74: Washington (U.S. Govt. Printing Office), 685-695.

Chamley, H., and Robert, C., 1979. Late Cretaceous to early Paleogene environmental evolution expressed by the Atlantic clay sedimentation. In Christensen, W. K., and Birkelund, T. (Eds.), Cretaceous/Tertiary Boundary Events Symposium, University of Copenhagen (Vol. 2), 71-77.

Chester, R., Elderfield, H., Griffin, J. J., Johnson, L. R., and Padgham, R. C., 1972. Eolian dust along Atlantic eastern margins. Mar. Geol., 13:91-106.

Ciesielski, P. F., and Wise, S. W., Jr., 1977. Geologic history of the Maurice Ewing Bank of the Falkland Plateau (southwest Atlantic sector of the Southern Ocean) based on piston and drill cores. Mar. Geol., 25:175-207.

Crook, K. A. W., and Belbin, L., 1978. The southwest Pacific area during the last 90 mill. years. J. Geol. Soc. Aust., 25:23-40.

Crook, K. A. W., and Feary, D. A., 1982. Development of New Zealand according to the fore-arc model of crustal evolution. Tectonophysics, 37:65-107.

Dauphin, J. P., 1980. Size Distribution of chemically extracted quartz used to characterize fine-grained sediments. J. Sed. Petrol., 50: 205-214.

Denton, G. H., and Armstrong, R. L., 1969. Miocene-Pliocene glaciations in southern Alaska. Am. J. Sci., 267:1121-1142.

Folger, D. W., 1978. Eolian dust in Marine sediments. In Fairbridge, R. W., and Bourgeois, J. (Eds.) The Encyclopedia of Sedimentology. Encyclopedia of Earth Sciences Series (Vol. 6): Stroudsburg, $\mathrm{Pa}$ (Dowden, Hutchinson, and Ross).

Gac, J. Y., 1979. Geochimie du bassin du lac Tchad: Bilan de l'altération, de l'érosion, et de la sédimentation [D.Sc. thesis]. Université de Strasbourg.

Glasby, G. P., 1971. The influence of aeolian transport of dust particles on marine sedimentation in the southwest Pacific. J. R. Soc. N. Z., 1:285-300.

Griffin, J. J., Windom, H., and Goldberg, E. D., 1968. The distribution of clay minerals in the World Ocean. Deep-Sea Res., 15: 433-459.

Hamon, B. V., 1970. Western boundary currents in the South Pacific. In Wooster, W. S. (Ed.), Scientific Exploration of the South Pacific: Washington (National Academy of Sciences), pp. 50-59.

Hayes, D. E., and Ringis, J., 1973. Sea-floor spreading in the Tasman Sea. Nature, 243:454-458.

Healy, T. R., 1970. Dust from Australia. Earth Sci. J., 4:106-116.

Holtzapffel, T., Bonnot-Courtois, C., Chamley, H., and Clauer, N., in press. Heritage et diagénèse dans la constitution des smectites nord-atlantiques (Crétacé-Paléogène). Bull. Soc. Geol. Fr.

Janecek, T. R., and Rea, D. K., 1983. Eolian deposition in the northeast Pacific Ocean: Cenozoic history of atmospheric circulation. Geol. Soc. Am. Bull., 94:730-738.

Keigwin, L. D., Jr., 1979. Late Cenozoic stable isotope stratigraphy and paleooceanography of DSDP sites from the east equatorial and north central Pacific Ocean. Earth Planet. Sci. Lett., 45:361-382. 1982. Stable isotope Stratigraphy and paleoceanography of Sites 502 and 503. In Prell, W. L., Gardner, J. V., et al., Init. Repts. DSDP, 68: Washington (U.S. Govt. Printing Office), 445-453.

Kemp, E. M., 1978. Tertiary climatic evolution and vegetation history in the Southeast Indian Ocean region. Palaeogeogr., Palaeoclimatol., Palaeoecol., 24:169-208.

Kennett, J. P., 1977. Cenozoic evolution of Antarctic glaciation, the Circum-Antarctic Ocean, and their impact on global paleoceanography. J. Geophys. Res., 82:3843-3860.

1978a. Cenozoic evolution of circumantarctic paleoceanography. In van Zinderen Bakker, E. M. (Ed.), Antarctic Glacial History and Paleoenvironments: Rotterdam (Balkema), pp. 41-56. 1978b. The development of planktonic biogeography in the Southern Ocean during the Cenozoic. Mar. Micropaleontol., 3: 301-345.

Kennett, J. P., Houtz, R. E., Andrews, P. B., Edwards, A. R., Gostin, V. A., Hajós, M., Hampton, M., Jenkins, D. G., Margolis, S. V., Ovenshine, A. T., and Perch-Nielsen, K., 1975. Cenozoic paleoceanography in the southwest Pacific Ocean, Antarctic glaciation, and the development of the Circum-Antarctic Current. In Kennett, J. P., Houtz, R. E., et al., Init. Repts. DSDP, 29: Washington (U.S. Govt. Printing Office), 1155-1170.

Kidson, E., 1930. Dust from Australia. N.Z. Sci. Tech., 11:417-418.

Knox, G. A., 1970. Biological oceanography of the South Pacific. In Wooster, W. S. (Ed.), Scientific Exploration of the South Pacific: Washington (National Academy of Sciences), pp. 155-182.

Lange, H., 1982. Distribution of chlorite and kaolinite in eastern Atlantic sediments off North Africa. Sedimentology, 29:427-432.

Leinen, M., and Heath, G. P., 1981. Sedimentary indicators of atmospheric activity in the Northern Hemisphere during the Cenozoic. Palaeogeogr., Palaeoclimatol., Palaeoecol., 36:1-21.

Lever, A., and McCave, I. N., 1983. Eolian components in Cretaceous and Tertiary North Atlantic sediments. J. Sed. Petrol., 53:811-832.

Loewe, F., 1943. Duststorms in Australia. Commonwealth Met. Bur., Bull. 28.

McCave, J. N., and Jarvis, J., 1973. Use of the Model T Coulter Counter in size analysis of the fine to coarse sand. Sedimentology, 20: 305-315.

Maillot, H., and Robert, C., 1984. Paleoenvironmental evolution of the Walvis Ridge deduced from inorganic geochemical and clay mineralogical data, Deep Sea Drilling Project Leg 74, Southwest Atlantic. In Moore, T. C., Jr., Rabinowitz, P. D., et al., Init. Repts. DSDP, 74: Washington (U.S. Govt. Printing Office), 663-683.

Marshall, P., and Kidson, E., 1929. The duststorm of October, 1929. N.Z. J. Sci. Tech., 10:291-299.

Mercer, J. H., 1976. Glacial history of southernmost South America. Quat. Res., 6:125-166.

Mercer, J. H., and Sutter, J. F., 1982. Late Miocene-earliest Pliocene glaciation in southern Argentina: implications for global ice-sheet history. Palaeogeogr., Palaeoclimatol., Palaeoecol., 38:185-206.

Mienert, J., 1981. Wind- und Flussfracht in rezenten und jungquartaeren Sedimenten im Kuestenbereich NW-Australiens [Diplomarbeit]. University of Kiel.

Millot, G., 1964. Geologie des argiles: Paris (Masson).

Moriarty, K. C., 1977. Clay minerals in southeast Indian Ocean sediments, transport mechanisms and depositional environments. Mar. Geol., 25:149-174.

Mudie, P. J., and Helgason, J., 1983. Palynological evidence for Miocene climatic cooling in eastern Iceland about $9.8 \mathrm{Myr}$ ago. $\mathrm{Na}$ ture, 303:689-692.

Mueller, G., 1967. Methods in sedimentary petrology. In Engelhardt, W. V., Fuechtbauer, H., and Mueller, G. (Eds.), Sedimentary Petrology (Part I): Stuttgart (Schweizerbart'sche Verlagsbuchhandlung).

Nelson, C. S., and Hume, T. M., 1977. Relative intensity of tectonic events revealed by the Tertiary sedimentary record in the Wanganui Basin and adjacent areas, New Zealand. N. Z. J. Geol. Geophys., 20:369-392.

Paquet, H., 1969. Evolution Géochimique des Minéraux Argilaux dans les Altérations et les Sols des Climats Meditérranéens et Tropicaux à Saisons Contrastées. Sci. Geol. Strasbourg, Mem. 30.

Parkin, D. W., 1974. Trade winds during the glacial cycles. Proc. $R$. Soc. London, Ser. A, 337:73-100.

Parkin, D. W., and Padgham, R. C., 1975. Further studies on trade winds during glacial cycles. Proc. $R$. Soc. London, Ser. A, 346: 245-260.

Pedro, G., 1968. Distribution des principaux types d'altération chimique à la surface du globe. Présentation d'une esquisse géographique. Rev. Geogr. Phys. Geol. Dyn., 10:457-470.

Ramage, C. S., 1970. Meteorology of the South Pacific tropical and middle latitudes. In Wooster, W. S. (Ed.), Scientific Exploration of the South Pacific: Washington (National Academy of Sciences), 16-29.

Rea, D. K., and Harrsch, E. C., 1981. Mass-accumulation rates of the non-authigenic inorganic crystalline (eolian) components of deepsea sediments from Hess Rise, Deep Sea Drilling Project Sites 464, 465, and 466. In Thiede, J., Vallier, T. L., et al., Init. Repts. DSDP, 62: Washington (U.S. Govt. Printing Office), 661-668. 
Rea, D. K., and Janecek, T. R., 1982. Late Cenozoic changes in atmospheric circulation deduced from North Pacific eolian sediments. Mar. Geol., 49:149-167.

Robert, C., 1982. Modalité de la sédimentation argileuse en relation avec l'histoire géologique de l'Atlantique sud [thesis]. Université d'Aix-Marseille.

Sarnthein, M., Tetzlaff, G., Koopmann, B., Wolter, K., and Pflaumann, U., 1981. Glacial and interglacial wind regimes over the eastern subtropical Atlantic and Northwest Africa. Nature, 293: 193-196.

Sarnthein, M., Thiede, J., Pflaumann, U., Erlenkeuser, H., Fuetterer, D., Koopmann, B., Lange, H., and Seibold, E., 1982. Atmospheric and oceanic circulation patterns off Northwest Africa during the past 25 million years. In von Rad, U., Hinz, K., Sarnthein, M. and Seibold, E. (Eds.), Geology of the Northwest African Continental Margin: Berlin (Springer Verlag), pp. 545-604.

Savin, S. M., Douglas, R. G., Keller, G., Killingley, J. S., Shaughnessy, L., Sommer, M. A., Vincent, E., and Woodruff, F., 1981. Miocene benthic foraminiferal isotope records: a synthesis. Mar. $\mathrm{Mi}$ cropaleontol., 6:423-450.

Shackleton, N. J., Backman, J., Zimmerman, H., Kent, D. V., Hall, M. A., Roberts, D. G., Schnitker, D., Baldauff, J. G., Desprairies A., Homrighausen, R., Huddlestun, P., Keene, J. B., Kaltenback, A. J., Krumsiek, K. A. O., Morton, A. C., Murray, J. W., and Westberg-Smith, J., 1984. Oxygen isotope calibration of the onset of ice-rafting and history of glaciation in the North Atlantic region. Nature, 307:620-623.

Shackleton, N. J., and Kennett, J. P., 1975. Paleotemperature history of the Cenozoic and the initiation of Antarctic glaciation: oxygen and carbon isotope analyses in DSDP Sites 277, 279, and 281. In Kennett, J. P., Houtz, R. E., et al., Init. Repts. DSDP, 29: Washington (U.S. Govt. Printing Office), 743-755.

Shackleton, N. J., and Opdyke, N. D., 1977. Oxygen isotope and paleomagnetic evidence for early northern hemisphere glaciation. $\mathrm{Na}$ ture, 270:216-219.

Sprigg, R. C., 1982. Alternating wind cycles of the Quaternary era and their influences on aeolian sedimentation in and around the dune deserts of southeastern Australia. In Wasson, R. J. (Ed.), Quaternary Dust Mantles of China, New Zealand and Australia: Canberra, pp. 211-240.

Stein, R., 1984. Zur neogenen Klimaentwicklung in Nordwest-Afrika und Palaeo-Ozeanographie im Nordost-Atlantik: Ergebnisse von DSDP-Sites 141, 366, 397 und 544B. Berichte-Reports, Geol. Pal. Inst. Univ, Kiel, 4.

, 1985a. Late Neogene changes of paleoclimate and paleoproductivity off Northwest Africa (DSDP Site 397). Palaeogeogr., Palaeoclimatol., Palaeoecol., 49:47-59. 1985b. Rapid grain-size analyses of silt and clay fractions by SediGraph 5000D: Comparison with Coulter Counter and Atterberg methods. J. Sed. Petrol.

Stein, R., and Sarnthein, M., 1984a. Late Neogene events of atmospheric and oceanic circulation offshore Northwest Africa: highresolution record from deep-sea sediments. In Coetzee, J. A., and van Zinderen Bakker, E. M. (Eds.), Palaeoecology of Africa (Vol. 16): Rotterdam (A. A. Balkema), 16:9-36. 1984b. Late Neogene oxygen isotope stratigraphy and terrigenous flux rates at Site 544B off Morocco. In Hinz, K., Winterer, E. L., et al., Init. Repts. DSDP, 79: Washington (U.S. Govt. Printing Office), 385-394.

Thiede, J., 1979. Wind regimes over the late Quaternary southwest Pacific Ocean. Geology, 7:259-262.

Thiede, J., Suess, E., and Mueller, P., 1982. Late Quaternary fluxes of major sediment components to the sea floor at the Northwest African continental slope. In von Rad, U., Hinz, K., Sarnthein, M., and Seibold, E. (Eds.), Geology of the Northwest African Continental Margin: Berlin (Springer Verlag), pp. 605-631.

van Andel, T. H., Heath, G. R., and Moore, T. C., 1975. Cenozoic History and Paleoceanography of the Central Equatorial Pacific Ocean. Geol. Soc. Am. Mem., 143.

van de Graaff, W. J. E., Crowe, R. W. A., Bunting, J. A., and Jackson, M. J., 1977. Relict Early Cainozoic drainages in arid Western Australia. Z. Geomorphol. N.F., 21:379-400.

Walker, P. H., and Costin, A. B., 1971. Atmospheric dust accession in south-eastern Australia. Aust. J. Soil Res., 9:1-5.

Weissel, J. K., and Hayes, D. E., 1972. Magnetic anomalies in the Southeast Indian Ocean. In Hayes, D. E. (Ed.), Antarctic Oceanology, II: The Australian-New Zealand Sector. Antarct. Res. Ser., 19: Washington (Am. Geophys. Un.), 165-196.

Windom, H. L., 1969. Atmospheric dust records in permanent snow fields: implications to marine sedimentation. Geol. Soc. Am. Bull., 80:761-782.

Woodruff, F., Savin, S. M., and Douglas, R. G., 1981. Miocene stable isotope record: a detailed deep Pacific Ocean study and its paleoclimate implications. Science, 212:665-667.

Wyrtki, K., 1962. The subsurface water masses in the Western South Pacific. Aust. J. Mar. Freshwater Res., 13:18-48.

Date of Initial Receipt: 2 August 1984 Date of Acceptance: 15 February 1985 

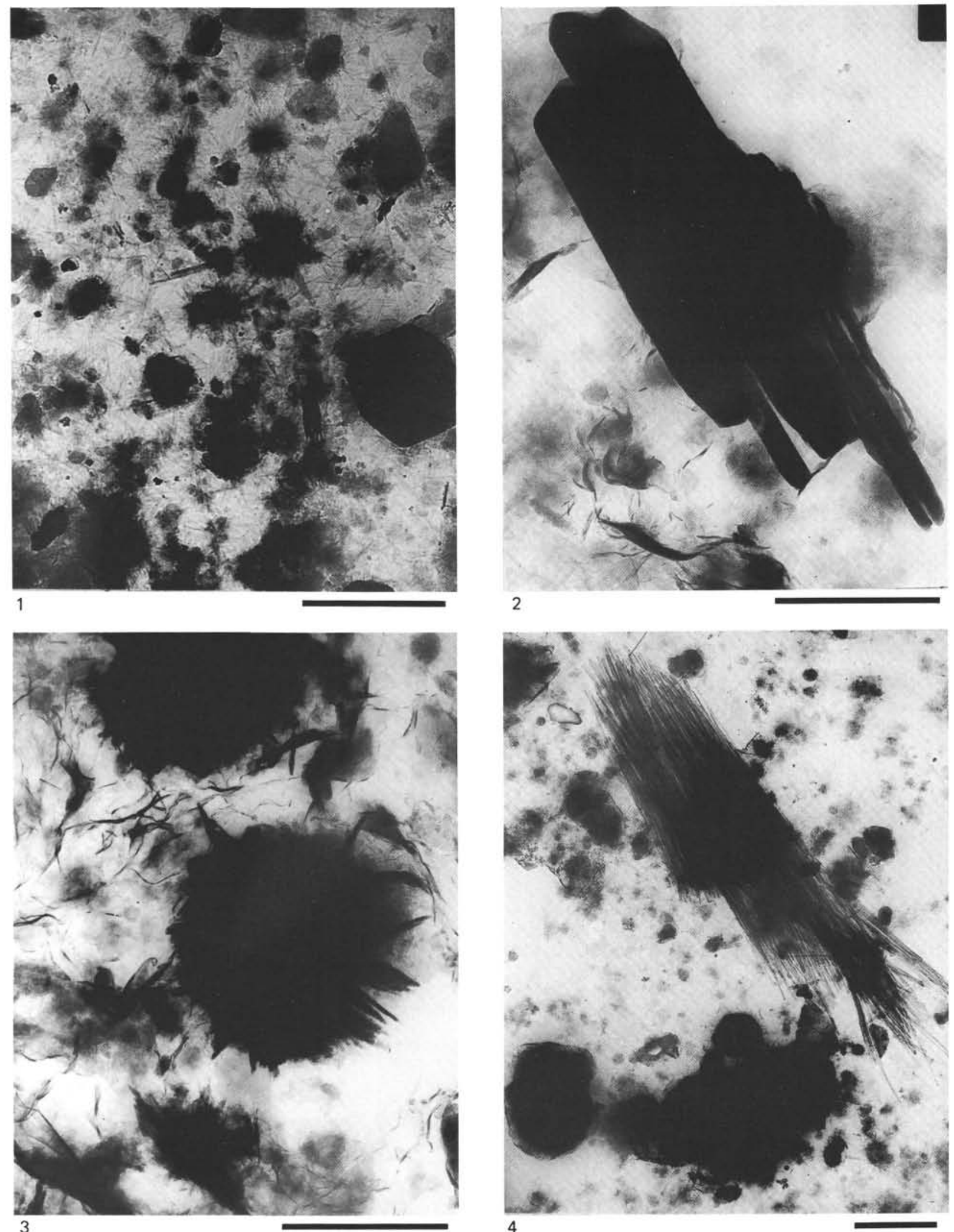

Plate 1. (Scale bar $=1 \mu \mathrm{m}$.) 1. Sample $588-16-5,80 \mathrm{~cm}(\times 25000)$; late Miocene; very fine laths, dispersed in the background or associated in geometrical figures in this clay fraction, containing $50 \%$ smectites associated with $25 \%$ illite and $25 \%$ kaolinite. 2. Sample $588-16-5,80 \mathrm{~cm}$ ( $\times 32000)$; late Miocene; thick-lathed particle. 3. Sample 590A-14-2, $50 \mathrm{~cm}(\times 32000)$; early Pliocene; globular packs of fine laths in this sample, containing $65 \%$ smectites, $10 \%$ illite, $5 \%$ irregular mixed-layer clays and $20 \%$ kaolinite. $\quad 4$. Sample $591-16-5$, 50 cm ( $\times 12500)$; early Pliocene; cluster of fibers resembling palygorskite/sepiolite. 